\title{
Ethnic Autonomy
}

\author{
Yu Sasaki ${ }^{\dagger}$ \\ This version: September 10, 2019
}

\begin{abstract}
This article explores the impact of the postal system on the consolidation of state authority in pre-modern Europe. Previous research indicates that geographical scale limits the state's ability to rule directly in this period. I argue that European states used the post to mitigate this constraint. Posts substantially reduced communications cost so that they became a crucial infrastructure of delivering information. I investigate the effect of postal service on the state's authority with a new data set on France. Using the persistence of non-French speakers as my outcome variable, I show that geographical distance from the capital reinforces the persistence, but postal expansion mitigates this challenge. I address the endogeneity concern that postal development is determined by resistance from minority people through two additional analyses: the first focuses on the impact of the post interacted with certain distances from Paris and the second incorporates factors outside France.
\end{abstract}

${ }^{*}$ I thank Jeffrey Arnold, Anthony Gill, Darryl Holman, Edgar Kiser, Melissa Lee, Amy Liu, Tristan James Mabry, Kyle Marquardt, Victor Menaldo, Christopher Paik, Steven Pfaff, Jaehyun Song, and participants at the 2016 ASN (Association for the Study of Nationalities) World Convention, the 2018 CAGE (Centre for Competitive Advantage in the Global Economy) Summer Workshop at the University of Warwick, the Spring 2019 Tokyo Conference on Economics of Institutions and Organizations, the 2019 Summer Workshop at the Japan Society for Quantitative Social Science, and the 2019 American Political Science Association for their constructive feedback to the previous drafts. Financial support from the Grant for Special Research Projects for Newly-hired Faculty (2018S-211) at Waseda University and the Japan Society for the Promotion of Science (18H05666) is gratefully acknowledged. All errors are mine.

${ }^{\dagger}$ Waseda Institute for Advanced Study, Waseda University. E-mail: ysasaki@aoni . waseda.jp. Website: yusasaki.squarespace.com 


\section{Introduction}

A growing body of research underscores the state's ability to execute policy as an important source of economic development (Andrews, Pritchett, and Woolcock 2017; Besley and Persson 2009, 2010; Fukuyama 2011). That the state plays an essential role in growth reflects the realization that today's wealthy states tend to have stronger capacity and enjoy tax revenues as greater proportions of their income than developing countries (Johnson and Koyama 2017). This scholarship is distinct from an influential literature in political economy which holds that the "right" set of institutions, most notably secure property rights, play a central role in growth (Acemoglu, Johnson, and Robinson 2005) and instead argues for cultivating a capability to bring about the intended policies.

How some states acquire an ability to consolidate authority and implement policy has not been widely studied. Classical works in the state-building literature focus largely on how states gain control over land as the primary source of taxation (Ertman 1997; Poggi 1978; Tilly 1992). The process of consolidation, by contrast, describes how the state shapes the behavior of mass population more directly. Recent research pays closer attention to this dimension of political development-the control of the population. It shows that the consolidation of state authority requires the ability to win compliance or acquiescence from the underlying population (Gorski 2003; Herbst 2000). ${ }^{1}$ Early state-builders tend to achieve this condition by providing public goods, to the extent that they can hold together diverse ethnic and linguistic groups in a single society (Wimmer 2016, 2018). By contrast, neighboring states can undermine states' effort to make their domestic authority more complete as indicated in recent international relations works (Lee 2018; Mylonas 2012). Given that politically developed states, such as those found in contemporary Western Europe and North America, have consolidated authority and enjoy a strong ability to undertake intended policies, these studies discuss why an indirect form of governance or incomplete sovereignty tend to perpetuate in many developing countries. In polities with a limited degree of authority, geographical attributes tend to hamper development, both politically and economically (Nunn and Puga 2012; Stasavage

\footnotetext{
${ }^{1}$ Scott (1998) warns the unintended consequences of the excess use of consolidated authority.
} 
2010).

In this paper, I provide a mechanism of the consolidation of state authority by exploring the development of the postal service in early-modern Europe. Beginning in the mid-fifteenth century, countries such as Germany, France, and England experimented with a new system in which they built relay stations at regular intervals across long distances. The institution proved effective and substantially reduced the cost of communication for European states. Although the initial service in England and France carried exclusively official mails, it eventually became open to the wider society and acquired the role of a public good that delivered merchandise. This transformation strengthened state capacity to enforce rule. As postal offices arrived at previously hard-to-reach locales in the countryside, they effectively brought the state closer the population. The presence of the post thus functioned as a tangible "proof" as to who is ruling the communities the post serves.

I then investigate the postal system as a political channel by using a new data set of 214 cities in early-modern France. France offers an adequate test as it was a precocious state-builder that was able to amass a large territory within Europe, but like its neighbors, it faced the challenge of centralizing authority due to institutional and fiscal fragmentation (Dincecco 2015). My empirical test focuses on the extent to which the French state reigned over language, a relatively low-profile and more difficult test on the consolidation of state authority. The language data comes from a rarely-used survey conducted in 1863 by the French government on the population, which is documented in Eugen Weber (1976). The date that the survey was taken is of importance, because France had achieved administrative centralization by then but did not yet initiate a universal curriculum that would require pupils to use French anytime in school. The data on the postal system consists of the distribution of relay stations in three periods - 1559, 1690, and 1792 - by drawing on previously unused published sources. It allows me to capture the impact of the postal infrastructure at a given time on subsequent political development. In addition, my empirical strategy controls for timespecific characteristics inside and outside France. For instance, I include the geographical distances to the border and the coast at the turn of the given century between 1400 and 1800 . To see if the way state capacity or the development of authority is driven by economic activity, I identify the access 
to major canals and the location of large-scale commercial fairs held in France. I also consider how outside factors moderate the degree to which Paris was able to impose authority. In particular, I incorporate the proximity to the German imperial post, the one that was not just open to those under German rule but provided extended service to a couple of cities in France including Paris and other major cities in Italy, Belgium, and even Spain. Thus my data set accounts for historically important known observables on political, economic, social, and geographical dimensions.

One of the main findings of this study is that geographical distance from Paris is positively and significantly associated with the persistence of non-French languages. In a fully-specified model, a 10-percent increase in the distance leads to a 1.7 percent increase in the proportion of non-Frenchspeaking communes. This finding is robust to the inclusion of a host of covariates inside and outside of France that may determine the country's consolidation of authority. Distance from post offices is also positively linked to non-French speakers, but the the post offices in 1792, the most recent year available, is the only one that has consistent and significant effects. To mitigate an endogeneity concern in which the location of the minority homelands drives the distribution of post offices, I subset the data set according to certain distances from Paris and estimate the effect of post offices in 1792 on authority consolidation. This scenario finds that proximity to the post interacted with the distance-to-Paris variable reduces the number of non-French speakers when locales are quite remote from the capital $-600 \mathrm{~km}$ or above, while no such relationship is seen within $600 \mathrm{~km}$. This finding is consistent with the initial goal when the postal system was first introduced in France in the midfifteenth century. By contrast, major outside influences such as proximity to conflict locations, the impact of the Protestant Reformation, and the German imperial post seem not to be systematically correlated with non-French speakers within France. The statistical analysis suggests that in times of indirect rule, geography and distance posed a constant challenge to the consolidation of state authority; while the expansion of the postal system went some way toward defeating the challenge, it alone was not sufficient.

I make two contributions in this paper. First, I provide a mechanism about how the construction of post offices strengthens the capacity of early-modern European states to rule. Postal ser- 
vice attracts increasing attention in the recent literature on social history, in which scholars seek to establish a connection between the early-modern post and the subsequent rise of what some call a "communications revolution" epitomized by the newspaper. This research highlights how the royal post constituted a critical infrastructure-essentially a public good as it ultimately came to serve populations - which dramatically reduced the cost of circulating information (Behringer 2006; Pettegree 2014; Raymond and Moxham 2016). In addition, much of recent empirical works that explores the impact of postal service on political and economic consequences draws evidence from the modern period (cf. Rogowski et al. Forthcoming). This study is among the first, if not the first, to examine the linkage between the post as state capacity and political development in the early-modern context. Second, I provide evidence on how the postal system contributed to the consolidation of state authority using a new data set of early-modern France. In pre-modern Europe, states had to resort to indirect rule, because geographical distance made the cost of direct rule remained prohibitively high until the rise of the railway. Contemporary developing states still face this challenge: recent empirical research finds the degree of authority to be inversely proportional to distance (Michalopoulos and Papaioannou 2013, 2014; Olsson and Hansson 2011). Consistent with the key findings in this literature, my paper offers a mechanism and evidence. More specifically, I demonstrate that pre-modern European states attempted to overcome the distance problem by installing postal service. Focusing on France, my analysis makes use of the expansion of its postal system across three centuries. But it also shows that this institution came short of consolidating authority on language policy. My paper's evidence also underscores the institutional dimensions on the origins of ethnolinguistic diversity. While previous scholarship finds strong associations between geographical attributes and diversity (Michalopoulos 2012), my work describes how states seek to gain control over diversity even in the face of overwhelming difficulties. 


\section{Conceptual Framework}

Pre-modern Europe was organized as "composite" states. They may possess a large swath of territory, but the authority structure was comprised of a mosaic of disparate subunits held together by treaties, allegiances, and marriages (Elliott 1992; Koenigsberger 1987; Nexon 2009). Constituting units were commonly allowed to retain their own laws, institutions, and customs in exchange for the oaths of political and military loyalty to the ruling crown. Spain fits this model well. Despite the fact that the scope of their authority was confined to Castile (Johnson and Koyama 2017), Spanish monarchs managed to cobble together a complex alliance made up of the kingdoms of Aragon and Valencia, the principality of Catalonia, and non-contiguous territories such as the Netherlands and the island of Sicily. In this period, indirect rule was the norm in governance. Local powerholders routinely resisted the state's incessant demands for greater revenue and tribute, yet monarchs, unable to rule directly, had few choices but to work with them by granting them tax exemptions and other privileges (Tilly 1992, 104). To win cooperation, the ruler had to bargain with these intermediaries to determine tax rates for individual local communities. This fiscal fragmentation proved to be not only highly inefficient because success may depend on the strength of the monarch relative to that of brokers (Spruyt 1994), but it was also unreliable because it gives each local elite an incentive to free-ride on others for the contributions (Dincecco 2015, 902). One institutional means to make the revenue stream more predictable was the regional assembly. It is another form of royal compromise Some European polities delegated this authority further to regional subunits (Stasavage 2010). The provincial estates of France fit this pattern. They provided a collective forum for negotiations with the crown. Although Paris had to cede autonomy, collective bargaining certainly reduced the transaction cost of revenue generation (Beik 2005; Campbell 2012).

At the same time, European states continued to invest in direct rule. One innovation designed to strengthen state authority is the post, particularly the system which arose in the late fifteenth century. It plays an essential role in reducing the cost of communication dramatically by building an infrastructure of how information spreads (Behringer 2006). ${ }^{2}$ Compared to inventions such as

\footnotetext{
${ }^{2}$ Historian Wolfgang Behringer stresses the historic significance of this development to the extent that it constitutes
} 
the mechanical clock and the movable-type printing press, the postal service is less technological progress than an institutional innovation. Although there is some empirical research on the effect of post offices in the contemporary context, no study to the best of my knowledge exists on the relationship between the communications system and state-building. ${ }^{3}$

In European history, the institutionalized postal service was known to be operational since Roman Emperor Augustus (r. 27 BCE-14 CE). It is estimated that couriers at the time traveled between 30 and $40 \mathrm{~km}$ a day given how lodging in which these travelers could stay was placed at such intervals on major Roman roads (Pettegree 2014, 21). The pace remained quite slow throughout the Middle Ages: in the fall of 1215, it took approximately 30 days from Liège to Rome and 40 days in the return trip in following January (Behringer 1990, 10-11). By the mid-fifteenth century, mails traveled 20$30 \mathrm{~km}$ on average and $50-60 \mathrm{~km}$ if the news was particularly urgent (Behringer 1990, 11). In 1449, it needed seven weeks from Nuremberg to Vienna.

A historic institutional innovation occurred at the turn of the sixteenth century, when Germany introduced the imperial post (Kaiserliche Reichspost). It was notable because it substantially improved the speed of the operation. Mails would now go an estimated $161 \mathrm{~km}$ a day, a six-fold increase from the average of $25 \mathrm{~km}$ half a century earlier (Behringer 1990, 12). For instance, couriers in 1505 carried mails in a 765-km route from Mechelen, a town near Brussels, to Innsbruck for 131 hours (or five days and eleven hours) (Behringer 1990, 10-11); if they traveled at the pace of 25km, it would have taken 30 days. ${ }^{4}$ Germany first experimented on the courier service in 1443 when Emperor Frederick III ordered the construction of a relay station over a 518-km route between Vienna and Feldkirch (Pettegree 2014, 36). ${ }^{5}$ The German imperial post is also innovative in that the state outsourced the operation to the noble family of Taxis who made the service public. It not only carried letters for royal and administrative purposes but also gave an access to other customers, in-

a "Communications Revolution" that undergirded the scientific revolution that followed.

${ }^{3}$ See Rogowski et al. (Forthcoming) for the literature and an empirical work on economic growth. As for political consequences, Perlman and Sprick Schuster (2016) examines the impact of access to postal routes on the growing share of votes among small political parties in the early-twentieth-century United States.

${ }^{4}$ The "as the crow flies" distance is $654 \mathrm{~km}$. In a quick internet search, it is roughly a three-hour flight distance today.

${ }^{5}$ Feldkirch is located today in the western corner of Austria and borders on Liechtenstein. 
cluding merchants and priests, to deliver not only letters and packages but also money, jewelery, and samples of textiles and spices (Behringer 2006,342). The pre-modern post was less a network of nodes than a collection of stations in which couriers on horseback carried letters from one relay post to the next. Figure 1 shows the location of the imperial post in the mid-sixteenth century.

\section{Figure 1: The distribution of the German imperial post in the mid-sixteenth century.}

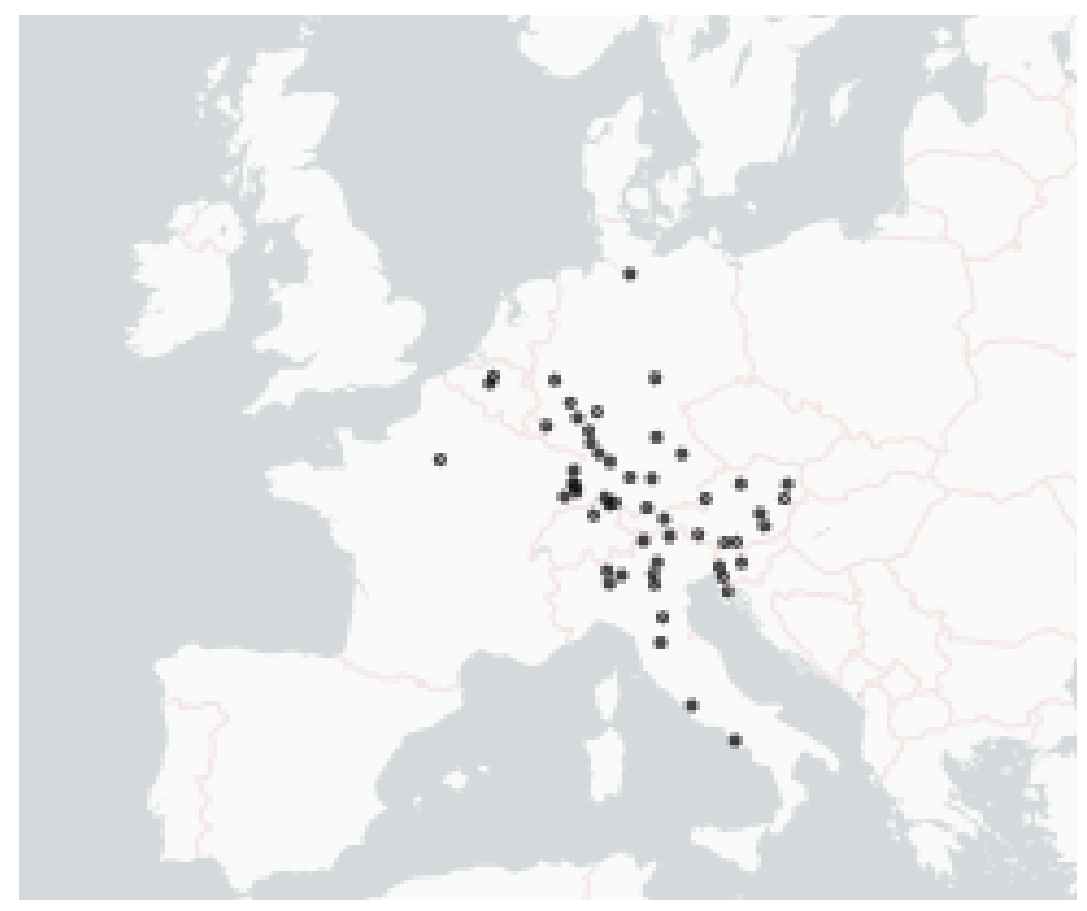

Source: See the Empirical Strategy section.

By contrast, postal service in neighboring countries such as England and France started exclusively royal at first. France followed suit with the 1464 decree soon after the German experiment. Under the French system, postmasters were assigned to relay stations to take care of horses and lodging (Allen 1972, ch. 1). The monarchy refused to allow the delivery of private letters on the crown roads and Francis I (r. 1515-47) also forbade any rival networks to be built alongside (Schobesgerger et al. 2016, 33-4). ${ }^{6}$ The exclusively official service persisted at least until 1630 (Schobesgerger et al. 2016, 35). In a similar vein, England started the own Treasury-funded postal service in the 1480s.

\footnotetext{
${ }^{6}$ Interestingly, France in the sixteenth century resisted the extension of the German imperial post within its territory although the German service reached Madrid and then the rest of the Iberian Peninsula, including Lisbon and Seville (Schobesgerger et al. 2016).
} 
Thereafter the cost of communication also reduced substantially-by the late sixteenth century it would require only 55 hours over a $280-\mathrm{km}$ route from London to York, a northern town, which used to take at least six days in 1484 (Brayshay, Harrison, and Chalkley 1998, 273, 279). Although these early-modern courier systems became more efficient over the next centuries, they were not without problems. One of the biggest challenges was high running costs that involved keeping stage posts functioning and horses fresh (Behringer 1990, 20). The initial English and French plans proved to be overly ambitious: when the monarchs who took the initiative died, the postal service contracted in the short-run for the financial shortage (Pettegree 2014, 37).

The postal institution bears an important implication for the consolidation of authority. As a public good, it would help strengthen state capacity where stations are built. As the system took root, more posts and routes were created, more (official) mails were carried, and the per-delivery cost became less expensive. Having established ways of passing information along allowed the state to disseminate information in a reliable manner. Thus the post would assist in bringing political order. Postbellum America is instructive. In the 1870s, the Republicans granted the Democrats the authority to appoint the postmaster-general who, in turn, had the authority to fill nearly 1,750 administrative positions on the postal service in the South. These account for approximately 40 percent of all civil-service positions and are second only to the Army. The North took advantage of the extent of the postal service to win compliance from the South with its authority and to suppress the seeds of southern separatism in the reconstruction of the U.S. state (Bensel 1990, 395-6). Moreover, the post had the effect of bringing the state closer to remote communities as the royal mail service passes through on a regular basis. It routinized the interactions between the state and its subjects. These interactions could make the enforcement of new rules or win compliance from taxpayers more effective. The importance of frequent interactions may be highlighted through the absence of postal offices. It was often the case that localities through which courier service passed enjoyed relatively paved roads. Those without it had much poorer transport, and subsidiary roads to postal ones remained inefficient. In late sixteenth-century England, it would take an estimated 15 hours from London to Andover over approximately $100 \mathrm{~km}$. From Andover to a nearby town of 
Wallop, located within $11 \mathrm{~km}$, would need additional six hours over a subsidiary route (Brayshay, Harrison, and Chalkley 1998). The establishment of a postal office or an official post constitutes a tangle public symbol of the extent of the state's reach and therefore authority.

One concern of endogeneity of the post as a form of state capacity is that the location of post offices may be dependent on local characteristics, observed or not. It is certain that relay stations are not distributed randomly within country. The state's decision to place new ones may be based on certain local conditions. In France, for example, there is an indication that Brittany initially saw the installing of Crown post offices as a form of invasion and thus until the 1620 s resisted the move (Schobesgerger et al. 2016, 34). At the same time, if the analysis focuses on postal expansion contained in a single country, one unobservable factor that may inform the development of state authority is influence from outside the country. This is a plausible scenario given how borders were nominal and "soft" in pre-modern times. My empirical strategy address these endogeneity concerns to identify accurately the effect of the postal system.

\section{Empirical Strategy}

This study addresses the consolidation of authority in early-modern European history. In premodern times, European states were characterized with composite polities, in which authority was fragmented and indirect rule was the norm. The postal service that arose in the late fifteenth century had the effect of not only making communications cheaper between the center and the periphery but also allowing the capital to observe the countryside frequently. In this paper, I focus on language as a proxy for authority consolidation over the population. Language is a difficult test of state capacity. Unlike taxation that involves passing interactions between the state and its subjects at the time of assessment and extraction, imposing a unitary language requires more frequent, prolonged, and invasive efforts by the state. ${ }^{7}$ The post may provide speakers of tongues other than that of the polit-

\footnotetext{
${ }^{7}$ To underscore this point, Jeffrey Herbst (2000, 126-31) discusses a reliance on indirect taxation and nontaxation sources of revenue allowed African states to not have to invoke mass loyalty based on language or other common cultural attributes in their political development.
} 
ical center with an incentive to switch by reducing the cost of access to information in the language of the capital and by routinizing communications with the center. Since this is a time-consuming effort that entails mass participation, assessing state capacity in language serves as a challenging test of the consolidation of authority in this period.

I draw evidence from French history. France is appropriate as it is a tough case. On the one hand, it is a precocious state-builder in Europe (Spruyt 1994; Strayer 1970). It amassed a large territory at the time of Carolingian rule and, despite the split, kept acquiring more throughout the early-modern period. The pace of centralization was relatively slow to come: France relied on a decentralized (i.e., inefficient) form of tax farming longer than its English neighbor (Johnson and Koyama 2014; Johnson 2006). In addition, Paris was an early starter in Europe of state-run postal offices in the mid-fifteenth century. The attempt to gain control over the circulation of political information makes France an adequate candidate to understand the effect of the instruments of political control. On the other hand, a high degree of ethnolinguistic diversity persisted throughout the pre-modern period. France is well-known today for its strong government-led effort to make immigrants conform to its cultural and linguistic standard (e.g., the 2004 ban to wear conspicuous religious symbols, most notably the Islamic veil, in public schools). It was not until the start of the Third Republic in 1870 did Paris legislate a universal curriculum requiring French to be the language of instruction in public schools. ${ }^{8}$ Before then, language served simply as an instrument of rule and the fluent speakers were limited to a fraction of the population, including government officials, literates, and local elites (Bell 2001, 171-2; Weber 1976, 71). ${ }^{9}$ In short, France is an adequate case because of its early interest in linguistic and cultural homogeneity but the lagged development of implementation capacity.

I assemble a new data set of 214 cities in France that cover ten minority ethnic groups on their

\footnotetext{
${ }^{8}$ There was a recognition of the absence of linguistic unity, which revolutionaries saw as a political liability. To illustrate, Henri Grégoire, a Catholic priest and a leading revolutionary, realized post-Revolution that "there is no patriotism in the countryside," and perceived that people's inability to communicate intelligibly to be an impediment to achieving political unity based on the revolutionary ideals (Weber 1976, 72, 98).

${ }^{9}$ It is important to note that linguistic unity at the state level in France did not begin with the 1539 Ordinance of Villers-Cotterêts issued by François I. Still in the books today, its goal was not to make French a unitary language in the royal domain but to make it the language of the court over Latin (Weber 1976, 70).
} 
attributes primarily of the early-modern period. It includes those cities that are under French jurisdiction today to control for the shifting territory over time. The city data draws on Nüssli (2011), which offers GIS (geographical information system)-based information on the location, administrative divisions, and political status for the subunits that existed at the final year of each century. The choice of the city as a proximate unit for ethnicity rests on observed patterns. Ethnic groups predominantly live in a clustered fashion and designate a hub city as their homeland "capital," around which economic activity flourishes and institutional development occurs. This empirical pattern allows me to use city-level attributes as useful proxies to collect attributes of ethnic groups and systematically examine them. I draw on Minahan (2000) to both identify the ethnic groups in today's French territory and specify the historical location of their homeland. I use this information to approximate the area of residence for these groups as displayed in Figure 2.

My data set is originally a time-series and cross-sectional one organized in fifty-year periods from 1400 to $1900 \mathrm{CE}$, but because the outcome variables are limited to a single time period, I limit statistical analysis to the cross-section. ${ }^{10}$ For identification I construct a number of covariates which account for time and can determine the value of the outcome variables.

\footnotetext{
${ }^{10}$ I also collected the information on the cities in the adjacent states that were once under French rule over this period. There are at least 256 cities in the dataset. However, I have dropped those that eventually fell outside of French authority today for the theoretical and methodological reasons. The theoretical rationale is that these cities were nominally "French" and never developed long-term, institutional connections with Paris, such as a provincial estate. The methodological reason is that limitations of data availability due to the lack of institutional ties make systematic analysis difficult.
} 
Figure 2: The geographical distribution of ten ethnic groups and the 214 cities in France.

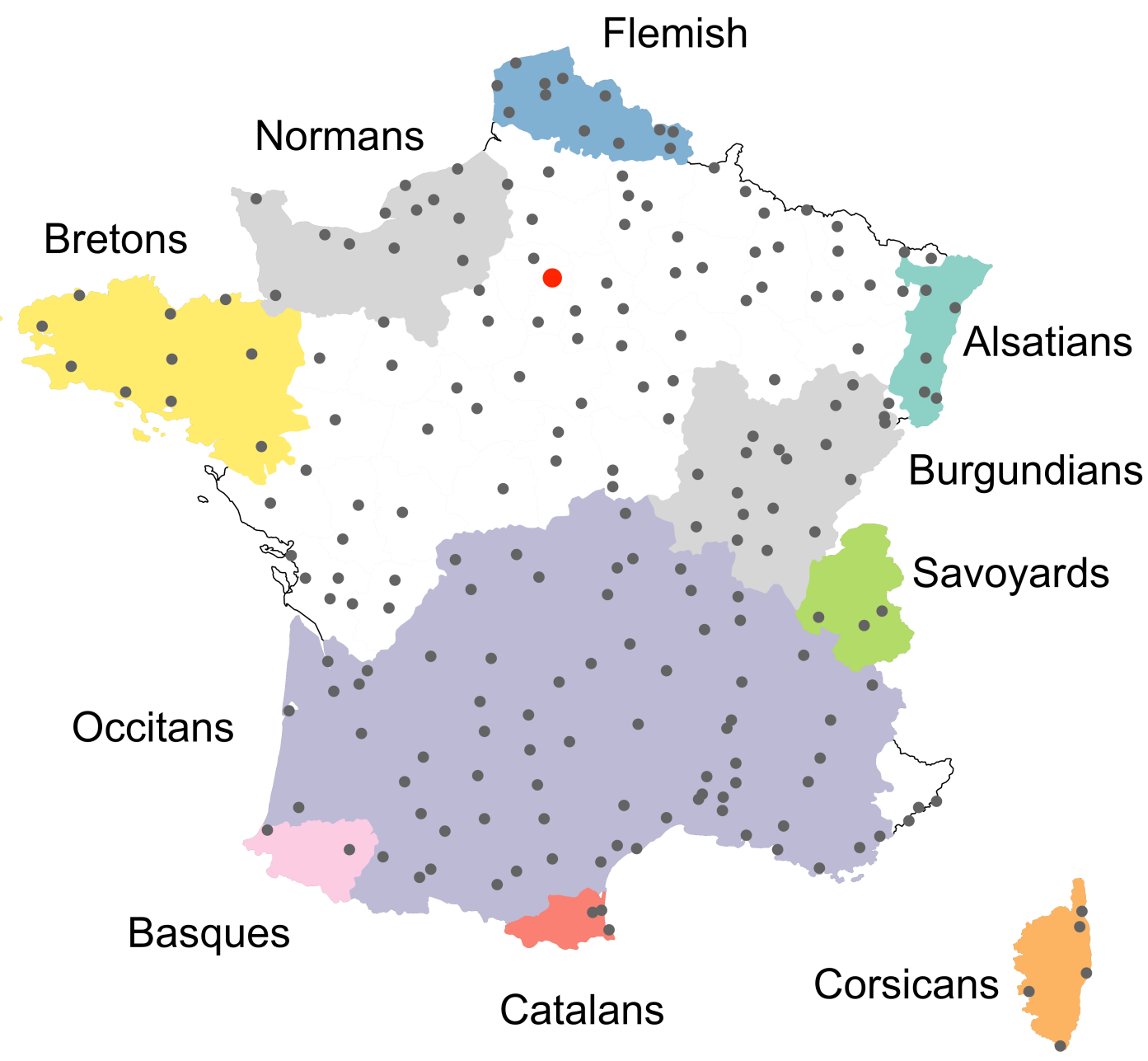

Notes: The gray dots indicate the cities; the red dot in the north indicates Paris. Ethnicity is color-coded individually, but the French-speaking groups (i.e., the Normans and Burgundians) get the same color. Source: Minahan (2000), Nüssli (2011), Simons and Fennig (2018).

I take an "expansive" approach about which minority ethnic groups are included in France. If I count only those whose homeland city is located within today's French territory, the Basques, the Catalans, and the Flemish would be removed as their main homeland cities are located outside France (Vitoria, Barcelona, and Brussels, respectively). For the Basques and the Catalans, for instance, the area along the Pyrenées was historically contested and its nominal owners frequently 
shifted between Spanish and French monarchs. State boundaries were less rigid before the modern era and this territorial fluidity in part allowed these groups to retain strong cultural connections across the borders through French cities such as Bayonne, Perpignan, and Lille (respectively for the Basques, the Catalans, and the Flemish). The colors that denote the "territory" of ethnic groups in Figure 2 simply designate the areas where non-French tongues are spoken on the level of the department (départment in French). It is important to note that these color-coded areas merely indicate where these minority individuals are expected to live. Neither do they serve as politically salient categories nor indicate that individuals of minority groups would recognize departmental boundaries as ethnic or politically salient boundaries.

If this distribution of the minority is a function of "under-consolidation," it is plausible to take it as a coarse proxy for the French state's capacity on culture. Given that "ethnicity" may involve different dimensions of cultural attributes, I construct three different indices. The first is the indicator called "ethnicity." I begin by creating a dummy variable for each of the ten ethnic groups, which equals one when a given city is considered part of the ethnic homeland. Then I aggregate these ten indicators to make an umbrella category that takes the value of one to represent all the color-coded regions in Figure 2. The second represents the "non-French" dimension, in which the indicator is coded one if a city as part of an ethnic homeland speaks the language other than French. It includes all ten but the Normans and the Burgundians who predominantly speak what linguists consider dialects of French. Third, I make an indicator for the "officially-recognized minority status." It is based on the 2008 constitutional revision in France, in which some non-French vernaculars were granted the status of being part of the country's "heritage" ("patrimoine de la France"). These include Alsatian, Basque, Breton, Catalan, Corsican, Flemish, and Occitan. 
Table 1: Descriptive statistics on independent variable.

\begin{tabular}{lrrrrrr}
\hline & $\mathrm{N}$ & mean & median & $\mathrm{sd}$ & $\min$ & $\max$ \\
\hline Distance from Paris $(\mathrm{km})$ & & & & & & \\
$\quad$ All & 214 & 373 & 350 & 198 & 0 & 986 \\
Ethnicity & 141 & 445 & 440 & 186 & 90 & 986 \\
Non-French-speaking & 112 & 494 & 497 & 173 & 159 & 986 \\
Official minority status & 109 & 495 & 502 & 175 & 159 & 986 \\
\hline
\end{tabular}

Source: See the Empirical Strategy section.

I briefly examine this hypothesis using one of my explanatory variables: the geographical distance from the capital. It is the geodesic distance (measured in kilometer) between Paris and a given city $i$ for $N=214$ cities. Table 1 reports the descriptive statistics on the distance variable with breakdowns according to the three minority indicators. The mean value of the distance from Paris for all 214 cities is $373 \mathrm{~km}$, while the mean for the subsets of cities under ethnicity and other categories increase by $70 \mathrm{~km}$ or more. In particular, groups that speak tongues other than French and receive the official minority status have $100 \mathrm{~km}$ or greater mean and median values than in all samples. Table 1 provides preliminary evidence that distance from the capital is positively linked to ethnic minority or non-French speakers and suggests that France's capacity to consolidate authority on culture attenuates over the distance.

The outcome variable focuses on the linguistic dimension of ethnicity as operationalized by the use of non-French languages in mid-nineteenth-century France. In the literature on ethnicity and nationalism, language is one of the most important dimensions with which to define ethnicity for a couple of reasons. It is relatively straightforward to quantify. Moreover, language is a handy measure as it reflects not just environmental factors such as geography but also political and economic activity. In my context, the persistence of non-French tongues may not only represent the limited reach of state capacity due to geographical distance from the capital, but it may also be a function of political institutions that determine the economic activity that creates linguistic divergence. A product of these forces may be summarized as "ethnic autonomy" for short. Language thus serves as a useful proxy for ethnicity in empirical analysis. 
The data on linguistic diversity in nineteenth-century France draws on Weber's Peasants into Frenchmen (1976). While typically cited as evidence of transformation in the social identity of the peasants in the countryside from the local one to a broader-that is, French-one, it also contains a wealth of untapped data before the change. The data comes from the 1863 survey conducted by the Ministry of Public Instruction and documents the extent to which French was spoken and taught as the language of instruction in each locality. It includes the number of French- and nonFrench-speakers at the level of commune, the administrative unit roughly equivalent of township or municipality, and are aggregated at the départment level. According to the survey, of the 37,510 communes across 89 départments, 8,381 (22.3 percent) spoke little to no French (Weber 1976, 67). Similarly, of the more than four million schoolchildren aged seven through thirteen in the survey, approximately 11.2 percent spoke no French and 37.1 percent could understand it but not write it. Weber notes government surveyors' incentive to highlight the "success" of the spread of the language over the patois such that the figures recorded therein are likely to be exaggerated (Weber 1976, 67). Thus these are probably conservative estimates. Still, the data in the survey is useful and was taken at an appropriate timing, because France under the Third Republic that arose in 1870 began to undertake the compulsory primary education policy aiming at standardizing the country's languages by French.

Figure 3 graphically displays the geographical distribution of the two outcome variables on a map. It clearly shows that in each panel high percentages of non-French speakers, represented in colors, are concentrated in provinces remote from Paris (the red dot). The data is shown in quantile, where a darker color indicates higher values in percentage. The darkest blue indicates the top quantile (75-100 percent); and the next darkest, the second quantile (50-74 percent). Since the median value is zero, the bottom two quantiles are omitted. The white area indicates the Frenchspeaking region, suggesting that the use of French was well established in it before the start of the Third Republic. The distribution of the data across the two panels looks similar, but it is crucial to distinguish them because of varying population size across the communes. 


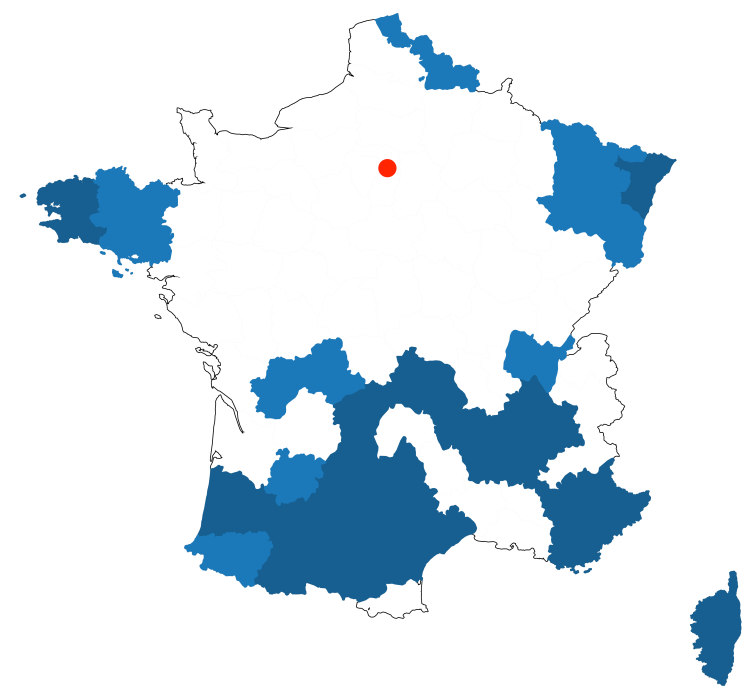

(a) Proportion of non-French-speaking communes

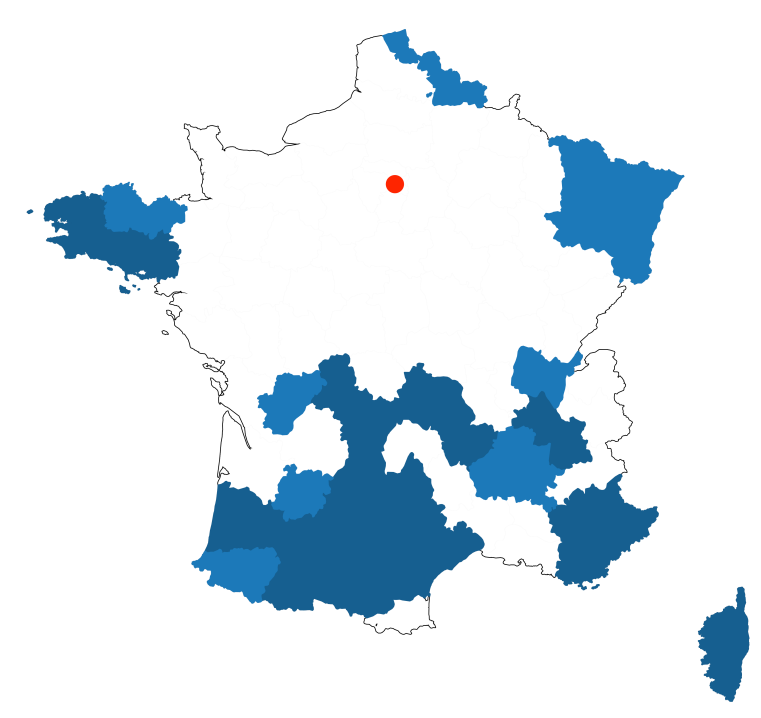

(b) Proportion of non-French-speaking population

Note: The data is from 1863. The red dot indicates Paris. Darker colors indicate higher proportions: The darkest blue indicates the top quantile (75-100 percent); and the next darkest, the second quantile (50-74 percent). Given that the median value is zero, the bottom two quantiles are dropped for readability.

Source: Weber (1976).

In addition to the distance variable, I include four other measures related to geography. The first two are land elevation above the sea level and terrain ruggedness, both of which are drawn from the GLOBE (Global Land One-kilometer Base Elevation project) database (GLOBE Task Team and others 1999). ${ }^{11}$ It is a $1 \mathrm{~km}$-by- $1 \mathrm{~km}$ gridded data on land terrain that covers the world. The last two measures provide the distance to the nearest border and coast. They represent the ease with which people in the peripheral parts of France are exposed to outside influence and are available from 1400 through 1800 given the changes in state size.

As a direct measure of state capacity, I use the distance to the nearest post office. I first identify the location of cities that bear a relay station and calculate the shortest distance to them for each city in my data set. To account for the evolution of state capacity over time, I look for sources in various

\footnotetext{
${ }^{11}$ The terrain ruggedness index (TRI) is originally proposed by Riley, DeGloria, and Elliot (1999).
} 
time periods. The 1559 data draws on Boissière (2016), the 1690 data is from Jaillot (1690), and the 1792 data comes from Arbellot and Lepetit (1987). ${ }^{12}$

The second variable on political institutions is the impact of the local parliament. Parts of today's French territory were incorporated at different times, and this historical process was a reason for the relatively late centralization of authorities (Johnson and Koyama 2017). One institutional solution to keep territorial integrity was to delegate authority to the local level in exchange for the regular stream of revenue. Throughout the ancien régime period, Paris established and relied upon the regional assemblies or provincial estates. These bodies represent the fragmented nature of French political development, which could, in turn, capture the autonomy of local cultural practices. I measure the impacts of institutional incorporation by counting the number of years that provincial estates were held up to the French Revolution, when all ancien-régime institutions were abolished. The data comes primarily from Kiser and Linton (2002) and is supplemented by Blockmans (1976) and Swann (2012). Not all départments had an assembly, but some had as many as almost 400 years of experience in the representative body between 1400 and 1789 .

The third political variable is war. The ruler's motive for greater revenue may drive the consolidation of authority by investing in state capacity. Involvement in battles nearby can boost the incentive to build post offices to relay up-to-date information to the capital faster. Similarly, war in Europe became only more expensive over time, which would push the ruler to ask local taxpayers for more contributions (Dincecco 2015; Kiser and Linton 2001). Conflict, by contrast, could disrupt mail deliveries. Protracted battles delay, halt, or destroy relay stations and postal roads and force couriers to find alternative, less reliable routes circumventing conflict zones (Pettegree 2014, 1756). These changes in state capacity can incorporate the hitherto geographically and administratively remote locales into direct rule by Paris. A reasonable hypothesis is that the closer the epicenter of a conflict is to the French territory, the more impact it is likely to have on the French. The data on the location of conflicts in early-modern European history draws on Dincecco and Onorato (2016), which provides the coordinates that war takes place. I use it to calculate the shortest distance to

\footnotetext{
${ }^{12}$ The Appendix presents the maps from which the data is generated.
} 
each conflict for each century from 1400 through 1700.

In addition, I construct two sets of controls. The first is a set of economic variables. The conventional proxy for growth in economic history is population growth whose standard source on the city level is Bairoch, Batou, and Chévre (1988). Based on it, I follow Bosker, Buringh, and van Zanden (2013) which updates the Bairoch et al. data. To account for time, I use the value of the most recent year for the study (1850) weighted by that of the base year (1400). Another proxy is the printing press. I consider it to be primarily an economic measure, since the profit motive is a main rationale for the technology's initial diffusion across Europe in the late fifteenth century. Printers were willing to bring a press to any city that is perceived to have a strong potential to recoup the fixed cost of setup and raise quick cash (Febvre and Martin 1976; Pettegree 2010). I record the first date of print in each city and count the number of presses by 1700 at the départment level. ${ }^{13} \mathrm{~A}$ third economic measure is access to commercial fairs. These annual events started in medieval times and served as a major contributor to the "Commercial Revolution" in Europe (Epstein 2000). They attracted armies of merchants who traded textiles, spices, and books. In France, the Champagne trade fairs were well-known and, once they declined in significance in the fourteenth century, Lyon took over as a hub in France. To account for this dimension of economic activity, I identify the location of eleven commercial fairs in France based on Raj (2018). ${ }^{14}$ I then calculate the geographical distance between each of them and 214 cities and count the number of fairs-holding cities within $50 \mathrm{~km} .{ }^{15}$

As the fifth measure of economic variables I include the distance to the nearest location of German imperial post in the sixteenth century. Unlike the French and English counterpart, the German system was more "public" by allowing nongovernmental actors to use the service from the beginning. It was also distinct in that it was a private-run organization by the Taxis family through the contract with the Holy Roman Empire and built posts not only within the Empire but extended its

\footnotetext{
${ }^{13}$ Data sources include Burke (2004), Clair (1976), Pettegree (2007), Conner (2001), Walsby (2011a,b), Bouchot (1890), and Reske (2007).

${ }^{14}$ The eleven cities that hold commercial fairs are Angers, Bordeaux, Caen, Lille, Lyon, Orleans, Paris, Rennes, Rouen, Toulouse, and Tours.

${ }^{15} \mathrm{I}$ use $50 \mathrm{~km}$ as a reasonable cutoff as overland transportation in Europe remained unreliable throughout the premodern period.
} 
reach to its neighboring cities, such as Brussels, Milan, Ljubljana, Paris, Rome, Vienna, and Zürich. The French cities known to receive the service at the time include Paris, Strasbourg, and Ensisheim (located near Strasbourg and Zürich). It is reasonable to expect locales closer to the German imperial post to take advantage of it, which may help them maintain autonomy when direct rule by Paris was difficult and costly. I identify at least 54 imperial posts at the turn of the seventeenth century based on Behringer (1990), Pettegree (2014), and Schobesgerger et al. (2016) and then calculate the shortest distance to these posts for each of the 214 French cities in the data set.

A cultural institution that matters in the context of this study is the university. Since its emergence in the Middle Ages, universities constituted prominent sites where individuals acquired human capital and systematic training in law. As economic historians have shown, access to university education may be associated with the development of legal institutions and state administration (Cantoni and Yuchtman 2014). ${ }^{16}$ In France, some universities established a system of exchanging letters among students and professors before the royal mail was born. As the service proved to be effective, it carried letters for other types of customers. I use Frijhoff (1996), Rüegg (2011), and Darby and Fullard (1970) to obtain the foundation date of universities. This is an indicator taking the value of one if a city gets a university, and I aggregate the number at the départment level.

Finally, I include several measures that might confound the analysis. One is the consequences of the Protestant Reformation. The historic religious movement in the fifteenth century, some scholars argue, had a discernible impact on institution-building related to the state and how actors sought political autonomy throughout Europe (Gorski 2003; Nexon 2009). During this tumultuous period, political elites were often under pressure to declare explicitly to take either side in public and implement necessary institutional changes, including the education system (Gorski 2003). Lay followers were encouraged by church ordinances to be literate and able to read the Bible in the vernacular (Dittmar and Meisenzahl 2016). Empirical research demonstrates that the closer a city is to the movement centers such as Wittenberg and Zürich, the more likely it is to accept Protestantism (Rubin 2014). Following Pfaff and Corcoran (2012), I measure the Reformation's impacts by taking

\footnotetext{
${ }^{16}$ Some scholars hypothesize that university training in law promoted state bureaucratization and the rise of absolutism in Central and Eastern Europe. See Ertman (1997).
} 
the shorter geographical distance to either Wittenberg or Zürich. I also include a set of historical measures on the long-run influence of the Roman Empire. The purpose is to account for early institution-building experience. The cities reached by the Romans had access to roads, which in turn gave them an opportunity to develop institutional capacity in economic activity and political organization. I use Talbert (2000), Hammond (1981), Åhlfeldt (2015), and Pleiades (2015) to collect information about the Roman legacy. I create an indicator taking the value of one if a city had major or minor Roman roads and a variable measuring the years under Roman rule. ${ }^{17} \mathrm{I}$ use these sources to calculate the number of years the given city was believed to be under Roman rule and identify whether a city had an access to the river. Finally, access to canals is included. Canals have played historically an important role in France by facilitating the transportation of goods for the traders located inland. I draw on a public report compiled in Becquey (1820) to identify the canals that were in service or about to be constructed by the early nineteenth century. I then georeference 37 of them and count the number of canals within the $50 \mathrm{~km}$ of each of the 214 cities. Table 2 provides the summary statistics of these variables in my data set.

\footnotetext{
${ }^{17}$ Following Bosker, Buringh, and van Zanden (2013), those cities with two or more major roads are coded "Roman hub" and those with one major road or one or more minor roads are coded cities with "Roman roads."
} 
Table 2: Summary statistics.

\begin{tabular}{|c|c|c|c|c|c|c|}
\hline & $\mathrm{N}$ & mean & median & sd & $\min$ & $\max$ \\
\hline \multicolumn{7}{|l|}{ Outcome variables ${ }^{\star}$} \\
\hline \multicolumn{7}{|l|}{ Proportion of } \\
\hline non-French-speaking communes & 214 & 0.28 & 0 & 0.4 & 0 & 1 \\
\hline non-French-speaking populations & 214 & 0.24 & 0 & 0.35 & 0 & 1 \\
\hline \multicolumn{7}{|l|}{ Political institutions variables } \\
\hline \multicolumn{7}{|l|}{ Distance from nearest post office $(\mathrm{km})$} \\
\hline in 1559 & 214 & 30 & 21 & 43 & 0 & 295 \\
\hline in 1690 & 214 & 27 & 0 & 44 & 0 & 295 \\
\hline in 1792 & 214 & 11 & 0 & 39 & 0 & 295 \\
\hline \multicolumn{7}{|l|}{ Distance from conflict location $(\mathrm{km})$} \\
\hline in 1400 & 214 & 142 & 112 & 102 & 1 & 397 \\
\hline in 1500 & 214 & 102 & 90 & 72 & 0 & 357 \\
\hline in 1600 & 214 & 123 & 111 & 76 & 0 & 354 \\
\hline in 1700 & 214 & 101 & 90 & 63 & 0 & 249 \\
\hline Years of provincial estates held ${ }^{*}$ & 214 & 118 & 36 & 143 & 0 & 398 \\
\hline \multicolumn{7}{|l|}{ Geography variables } \\
\hline Elevation (m) & 214 & 180 & 132 & 195 & 2 & 1,304 \\
\hline Terrain ruggedness (m) & 214 & 65 & 40 & 80 & 1 & 557 \\
\hline \multicolumn{7}{|l|}{ Distance to nearest coast $(\mathrm{km})$} \\
\hline in 1400 & 214 & 173 & 159 & 131 & 1 & 502 \\
\hline in 1500 & 214 & 157 & 133 & 136 & 0 & 470 \\
\hline in 1600 & 214 & 158 & 133 & 136 & 0 & 470 \\
\hline in 1700 & 214 & 156 & 132 & 136 & 0 & 469 \\
\hline in 1800 & 214 & 150 & 130 & 128 & 0 & 440 \\
\hline \multicolumn{7}{|l|}{ Distance to nearest border (km) } \\
\hline in 1400 & 214 & 58 & 46 & 46 & 1 & 231 \\
\hline in 1500 & 214 & 113 & 86 & 104 & 1 & 519 \\
\hline in 1600 & 214 & 129 & 101 & 118 & 1 & 519 \\
\hline in 1700 & 214 & 152 & 127 & 132 & 1 & 579 \\
\hline in 1800 & 214 & 199 & 180 & 138 & 1 & 616 \\
\hline
\end{tabular}

continued on next page 
continued from previous page

\begin{tabular}{|c|c|c|c|c|c|c|}
\hline & $\mathrm{N}$ & mean & median & sd & $\min$ & $\max$ \\
\hline \multicolumn{7}{|l|}{ Economic variables } \\
\hline \multicolumn{7}{|l|}{ Population size in 1850 weighed by } \\
\hline population in 1400 (in thousands) & 214 & 1.76 & 0 & 5.6 & 0 & 54 \\
\hline Number of printing presses by $1700^{*}$ & 214 & 0.77 & 1 & 0.66 & 0 & 3 \\
\hline \multicolumn{7}{|l|}{ Number of cities holding commercial fairs } \\
\hline within $50 \mathrm{~km}$ & 214 & 0.14 & 0 & 0.35 & 0 & 1 \\
\hline Number of canals within $50 \mathrm{~km}$ & 214 & 0.56 & 0 & 0.96 & 0 & 4 \\
\hline \multicolumn{7}{|l|}{ Distance from nearest imperial posts } \\
\hline in sixteenth-century Germany $(\mathrm{km})$ & 214 & 278 & 250 & 173 & 0 & 665 \\
\hline \multicolumn{7}{|l|}{ Cultural variables } \\
\hline Number of university ${ }^{\star}$ & 214 & 0.36 & 0 & 0.52 & 0 & 2 \\
\hline \multicolumn{7}{|l|}{ Control variables } \\
\hline Distance from Wittenberg (km) & 214 & 939 & 944 & 224 & 483 & 1,401 \\
\hline Distance from Zürich (km) & 214 & 509 & 511 & 193 & 86 & 976 \\
\hline Hub Roman road & 214 & 0.29 & 0 & 0.45 & 0 & 1 \\
\hline Roman road & 214 & 0.7 & 1 & 0.46 & 0 & 1 \\
\hline Years under Roman rule & 214 & 384 & 503 & 205 & 0 & 503 \\
\hline Access to navigable river under Rome & 214 & 0.7 & 1 & 0.46 & 0 & 1 \\
\hline
\end{tabular}

Notes: ${ }^{*}$ placed at the end of variable description denotes that data is observed at the level of départment.

Source: See the Empirical Strategy section.

\section{Estimation Results}

\section{Basic Correlations}

I first present unconditional relations between the outcome variables and the main explanatory variable. Figure 4 displays a scatter plot on non-French-speaking populations, aggregated at the départment level, regressed on geographical distance from Paris. The black labels indicate départments that are generally non-French-speaking; and the gray ones, French-speaking. It indicates that non-French-speaking départments tend to be concentrated at $400 \mathrm{~km}$ or more distant from Paris (the average distance for all départments is $367 \mathrm{~km}$ ). By contrast, French-speaking regions are more likely to be found in the closer distances. The bivariate relationship is highly positive with the cor- 
relation coefficient of 0.654 . To explore this association more systematically, I adopt the following three steps: First, I consider the within-country factors without state-capacity variables. Second, I include the post office locations to estimate the impact of political development. The third step incorporates the outside influence.

Figure 4: The scatter plot on the relationship between non-French-speaking population and geographical distance from Paris.

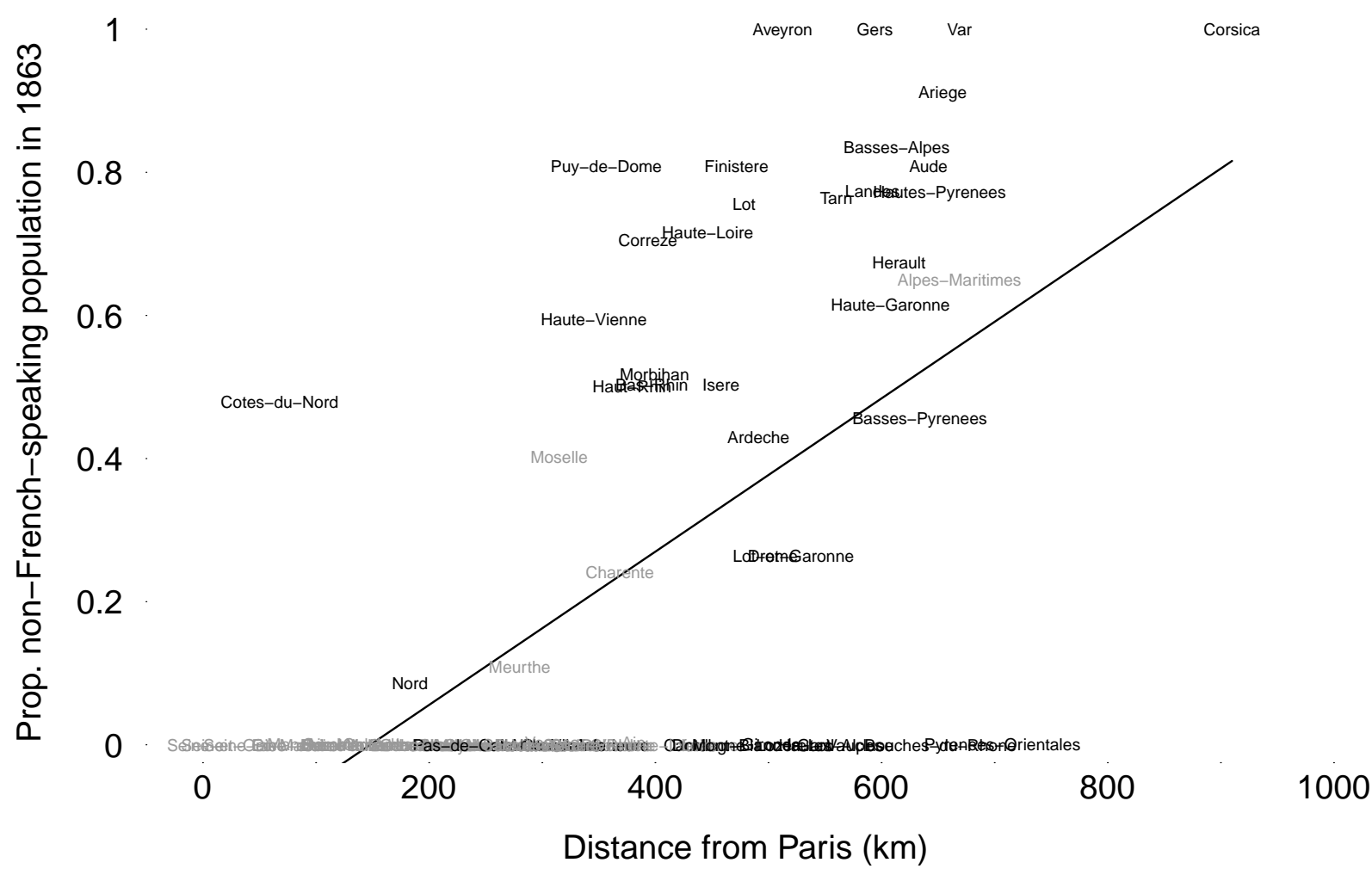

Notes: $N=88$. Départment names are shown on the plot. The black labels denote generally non-French-speaking; and the gray, French-speaking. The plot shows the fitted line.

Source: See the Empirical Strategy section. 


\section{Impact of within-country factors}

First, I investigate how within-country characteristics affect the consolidation of state authority in France using the following reduced form:

$$
\begin{aligned}
& \text { Autonomy }_{i d}=\alpha_{1}+\beta_{1} \text { Distance from Paris }_{i d}+ \\
& \delta_{1} \text { Distance from the } \text { border }_{i d} \times \lambda_{1} \text { Number of canals within } 50 \mathrm{~km}_{i d}+ \\
& \eta_{1} \text { Distance from the coast }_{i d} \times \lambda_{1} \text { Number of canals within } 50 \mathrm{~km}_{i d}+\gamma_{1} X_{i d}+\epsilon_{i d} \text {. }
\end{aligned}
$$

Autonomy $_{i}$ is proxied by the proportion of non-French speakers (either non-French-speaking communes or populations) for city $i, \beta$ is my main parameter of interest in this equation, and $\delta$ and $\eta$ account for the boundary effects which are averaged between 1400 and 1800. To assess whether proximity to canals boost these boundary effects, I include an interaction for each. $\gamma$ represents a vector of covariates on within-country factors $X$. Since the outcome variable is observed at the départment level, I use $d$ to cluster the estimation on this level by using robust standard errors.

Table 3 documents within-country characteristics on the consolidation of authority. ${ }^{18}$ In the bivariate model, a 10-percent increase in the distance from Paris leads to a 2.7 percent increase in the proportion of non-French-speaking communes (Model 1). The magnitude drops by 20 percent or so when a host of covariates are included but remains robust. The negative sign in the distance to borders means that proximity to neighboring countries makes people use French more. By contrast, the positive sign in the distance to the coast shows the opposite effect. The interaction models bear a positive but not significant impact (Models 5 and 6). This result suggests that among geographical factors, the distance from the capital is most consistent in understanding the consolidation of authority.

\footnotetext{
${ }^{18}$ Full results, including estimations for the other outcome variable on the proportion of non-French-speaking populations, are available in the Appendix.
} 
Table 3: OLS outputs of the impact of within-country factors on the consolidation of authority in France.

\begin{tabular}{|c|c|c|c|c|c|c|}
\hline \multirow[t]{2}{*}{ Dependent variable } & \multicolumn{6}{|c|}{ Proportion of non-French-speaking communes } \\
\hline & (1) & $(2)$ & (3) & $(4)$ & $(5)$ & (6) \\
\hline \multirow[t]{2}{*}{ Log distance to Paris } & $0.269^{* * *}$ & $0.196^{* *}$ & $0.234^{* * *}$ & $0.204^{* *}$ & $0.209^{* *}$ & $0.219^{* *}$ \\
\hline & $(0.075)$ & $(0.087)$ & $(0.089)$ & $(0.090)$ & $(0.084)$ & $(0.088)$ \\
\hline Log distance to border & & -0.060 & & -0.064 & $-0.082^{*}$ & -0.051 \\
\hline averaged, $1400-1800$ & & $(0.045)$ & & $(0.047)$ & $(0.047)$ & $(0.044)$ \\
\hline Log distance to border $\times$ & & & & & 0.088 & \\
\hline number of canals within $50 \mathrm{~km}$ & & & & & $(0.056)$ & \\
\hline Log distance to coast & & & 0.015 & 0.021 & 0.029 & 0.004 \\
\hline averaged, $1400-1800$ & & & $(0.033)$ & $(0.028)$ & $(0.025)$ & $(0.028)$ \\
\hline Log distance to coast $\times$ & & & & & & 0.037 \\
\hline number of canals within $50 \mathrm{~km}$ & & & & & & $(0.030)$ \\
\hline Number of canals within $50 \mathrm{~km}$ & & -0.053 & -0.048 & -0.054 & $-0.468^{*}$ & -0.209 \\
\hline & & $(0.039)$ & $(0.039)$ & $(0.038)$ & $(0.261)$ & $(0.140)$ \\
\hline Controls & & $\checkmark$ & $\checkmark$ & $\checkmark$ & $\checkmark$ & $\checkmark$ \\
\hline Observations & 214 & 214 & 214 & 214 & 214 & 214 \\
\hline
\end{tabular}

Notes: Robust standard errors clustered on the départment level for all models. ${ }^{\star *}$ denote $p<0.01{ }^{\star *} p<0.05$, and ${ }^{\star}$ $p<0.1$.

The second step considers the impact of state capacity more directly. My proxy in this study is the distance to the nearest city that hosts a relay station of the postal system. The measure implies proximity to the reach of the French state across the country whose data is available for three periods-1559, 1690, and 1792. As Figure 5 indicates, the number of postal stations increases from 99 to 114 to 175 . I include these measures to assess the impact of the development of state capacity on the consolidation of authority. 
Figure 5: Location of post offices across three centuries.

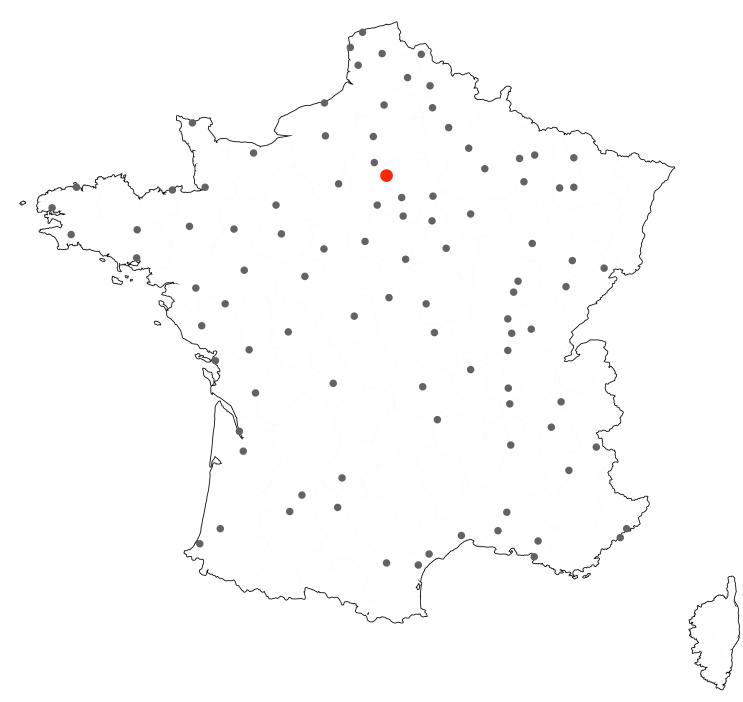

(a) 99 Post Offices in 1559

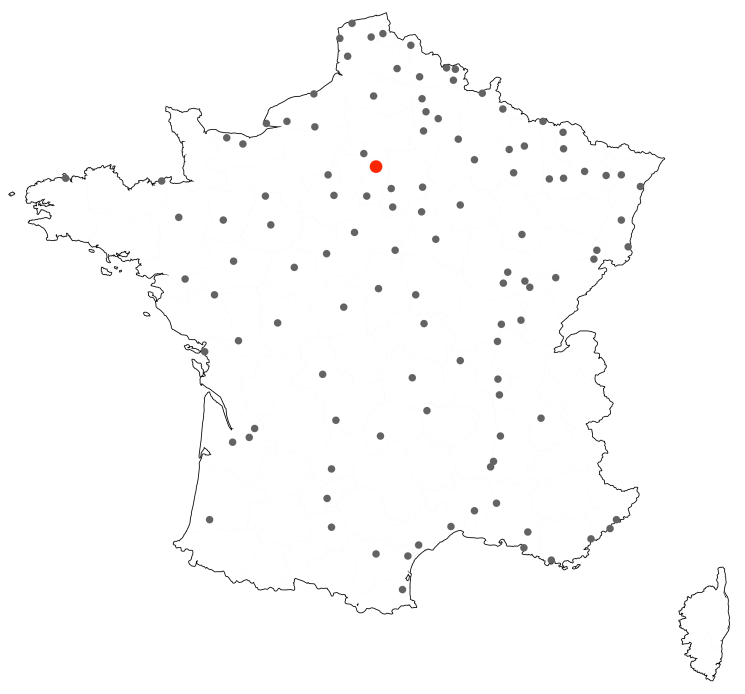

(b) 114 Post Offices in 1690

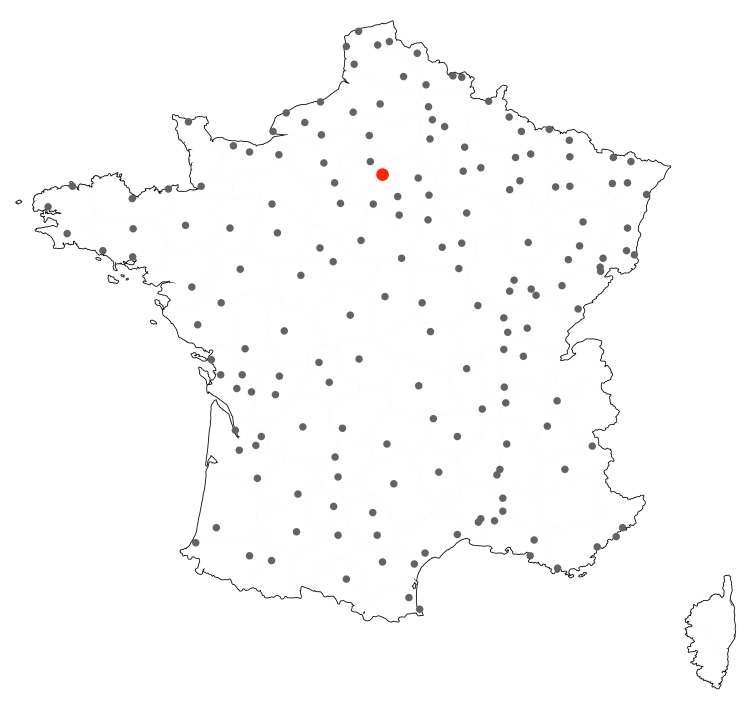

(c) 175 Post Offices in 1792

Note: The red dot indicates Paris.

Source: Boissière (2016) for 1559, Jaillot (1690) for 1690, and Arbellot and Lepetit (1987) for 1792. 
Table 4: OLS outputs of the impact of state capacity on the consolidation of authority in France.

\begin{tabular}{lccccccc}
\hline Dependent variable & \multicolumn{7}{c}{ Proportion of non-French-speaking communes } \\
& $(1)$ & $(2)$ & $(3)$ & $(4)$ & $(5)$ & $(6)$ & $(7)$ \\
\hline Log distance to Paris & $0.181^{* *}$ & $0.188^{* *}$ & $0.180^{* *}$ & $0.175^{* *}$ & $0.168^{* *}$ & $0.174^{* *}$ & $0.166^{* *}$ \\
& $(0.086)$ & $(0.085)$ & $(0.083)$ & $(0.084)$ & $(0.081)$ & $(0.081)$ & $(0.080)$ \\
Log distance to post offices & $0.035^{* *}$ & & & $0.029^{*}$ & 0.024 & & 0.021 \\
$\quad$ in 1559 & $(0.015)$ & & & $(0.016)$ & $(0.015)$ & & $(0.016)$ \\
in 1690 & & $0.029^{*}$ & & 0.019 & & 0.015 & 0.008 \\
& & $(0.016)$ & & $(0.017)$ & & $(0.015)$ & $(0.016)$ \\
in 1792 & & & $0.068^{* * *}$ & & $0.060^{* * *}$ & $0.062^{* * *}$ & $0.057^{* * *}$ \\
& & & $(0.021)$ & & $(0.022)$ & $(0.021)$ & $(0.022)$ \\
Log distance to border & -0.054 & -0.064 & -0.036 & -0.056 & -0.033 & -0.038 & -0.034 \\
$\quad$ averaged, 1400-1800 & $(0.044)$ & $(0.043)$ & $(0.039)$ & $(0.042)$ & $(0.039)$ & $(0.039)$ & $(0.039)$ \\
Log distance to coast & 0.021 & 0.028 & 0.032 & 0.026 & 0.031 & 0.035 & 0.033 \\
$\quad$ averaged, 1400-1800 & $(0.026)$ & $(0.026)$ & $(0.025)$ & $(0.026)$ & $(0.025)$ & $(0.025)$ & $(0.025)$ \\
& & & & & & & \\
Controls & $\checkmark$ & $\checkmark$ & $\checkmark$ & $\checkmark$ & $\checkmark$ & $\checkmark$ & $\checkmark$ \\
Observations & 214 & 214 & 214 & 214 & 214 & 214 & 214 \\
\hline
\end{tabular}

Notes: Robust standard errors clustered on the départment level for all models. ${ }^{* *}$ denote $p<0.01{ }^{* *} p<0.05$, and ${ }^{*}$ $p<0.1$.

I estimate the following equation on the expansion of the postal system:

$$
\begin{aligned}
& \text { Autonomy }_{i d}=\alpha_{2}+\beta_{2} \text { Distance from Paris } \\
& i d
\end{aligned}
$$

Equation 2 adds three sets of $\theta$ that capture the impact of proximity to the post office in 1559, 1690, and 1792. $\gamma_{2}$ now includes the distance to the border or the coast but omits the interactions in the previous equation. Table 4 documents this estimation. It finds positive associations between the distances to post offices and non-French-speaking people. The results support the hypothesis that the more remote cities are from the post offices, the more communes are likely to use language other than French. For each period, the magnitude is positive and significant (Models 1-3) but is not robust when combined with other periods. The exception is the post offices in 1792 whose effects are significant across the models. This result suggests that the French state was able to expand its reach over the early-modern period. At the same time, the distance to Paris remains robust. It is 
important to note that its impact drops by up to 18.6 percent when all three measures of post offices are included (Model 7). These findings suggest, first, that the effort of Paris to consolidate authority across the country moderates geography's impact and, second, that although Paris sought to install a more direct form of governance, it had difficulty overcoming the challenge of the geographical distance.

As discussed above, one concern of endogeneity is that certain minority groups resist the establishment of post offices as it would undermine their autonomy. As Figure 5 shows, relay stations were sparse in Brittany (the eastern part of France) and in parts of Occitania (the south west) up to 1690 . The distribution may be due to this resistance. But more post offices appear by the time of the French Revolution. To check the endogeneity concern, I focus on the post offices built by 1792. Figure 6 summarizes the steps. First, I subset the 1792 data according to certain distances from Paris. As the figure shows, the observations are grouped by the distances from Paris, from the shortest to the longest, at the $200 \mathrm{~km}-, 400 \mathrm{~km}-, 600 \mathrm{~km}-$, and $800 \mathrm{~km}$-radius. The groups are color-coded based on the given radius. Blue denotes those that the post is constructed, magenta denotes cities without it, and gray indicates those beyond the $800 \mathrm{~km}$-radius range. 
Figure 6: The distribution of the French post offices in 1792 based on certain distances from Paris.

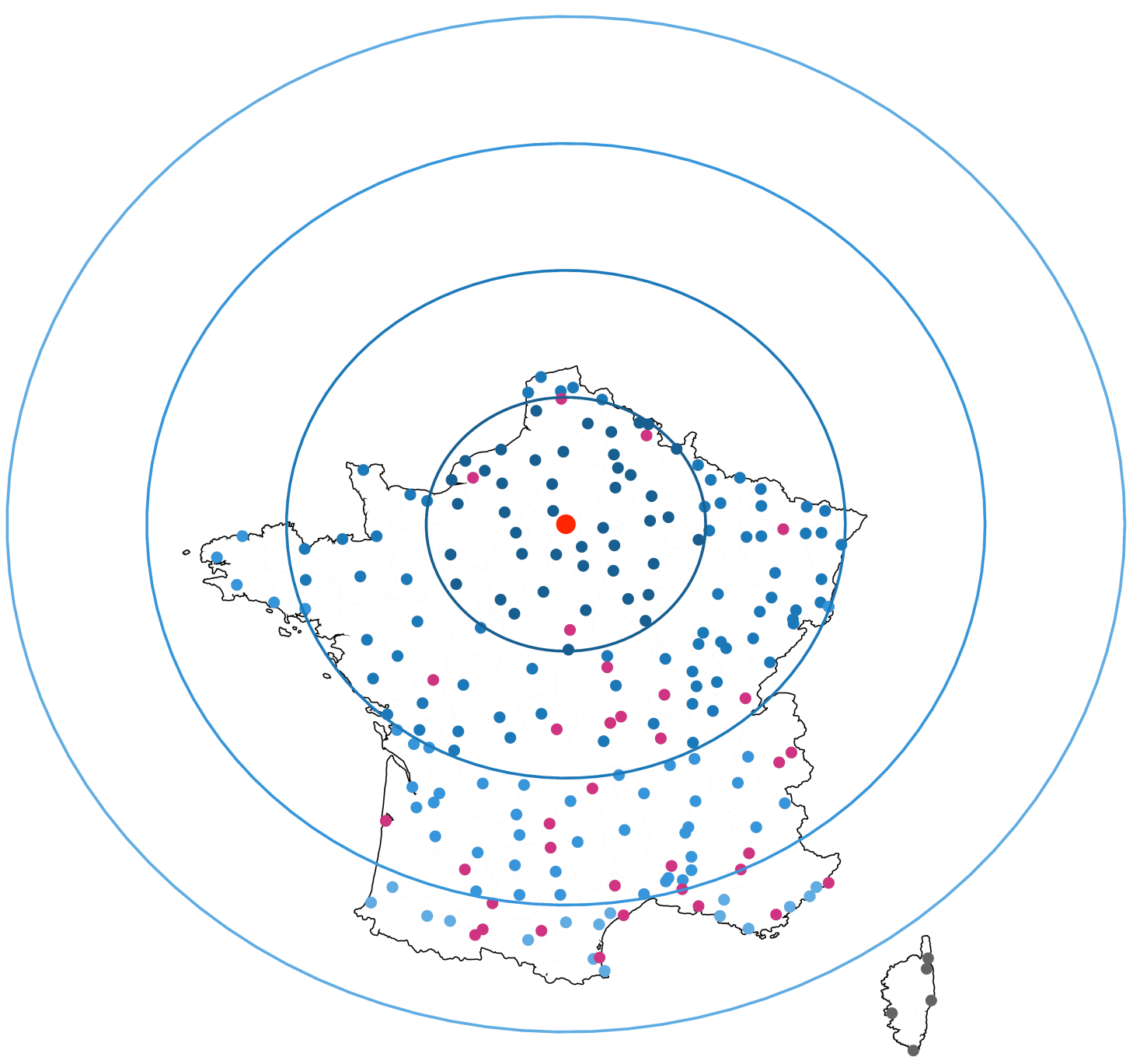

Notes: The circles refer to the distances from Paris, from the shortest to the longest, at $200 \mathrm{~km}, 400 \mathrm{~km}, 600 \mathrm{~km}$, and $800 \mathrm{~km}$ in radius. The location of post-office cities are color-coded in accordance with the circles. Blue denotes cities with the post, magenta without it, and gray outside the $800 \mathrm{~km}$ radius.

Source: See the Empirical Strategy section.

I estimate the impact of the post based on this classification. To understand the relationship between the post and the distance to Paris, I employ an interaction model. Instead of the measure on the distance from post offices, I re-code it by using an indicator variable taking the value of one if a city has the post at the given radius and zero otherwise. The findings are reported in Table 5. 
Table 5: OLS outputs exploring the variation of the post offices in 1792 in France.

\begin{tabular}{lcccc}
\hline \multirow{2}{*}{$\begin{array}{c}\text { Dependent variable } \\
\text { Distance from Paris within }\end{array}$} & \multicolumn{4}{c}{ Proportion of non-French-speaking communes } \\
\cline { 2 - 5 } & $\begin{array}{c}200 \mathrm{~km} \\
(1)\end{array}$ & $\begin{array}{c}400 \mathrm{~km} \\
(2)\end{array}$ & $\begin{array}{c}600 \mathrm{~km} \\
(3)\end{array}$ & $\begin{array}{c}800 \mathrm{~km} \\
(4)\end{array}$ \\
\hline Log distance to Paris & -0.375 & 0.330 & $0.541^{* * *}$ & $0.560^{* * *}$ \\
& $(0.276)$ & $(0.294)$ & $(0.169)$ & $(0.123)$ \\
Post office in 1792 & -1.933 & 1.355 & $2.097^{* *}$ & $2.199^{* * *}$ \\
& $(1.412)$ & $(1.566)$ & $(0.895)$ & $(0.689)$ \\
Log distance to Paris $\times$ & 0.372 & -0.257 & $-0.377^{* *}$ & $-0.394^{* * *}$ \\
Post office in 1792 & $(0.273)$ & $(0.297)$ & $(0.159)$ & $(0.119)$ \\
& & & & \\
Controls & $\checkmark$ & $\checkmark$ & $\checkmark$ & $\checkmark$ \\
$N$ post offices in 1792 & 44 & 114 & 158 & 174 \\
Observations & 49 & 128 & 182 & 209 \\
\hline
\end{tabular}

Notes: Robust standard errors clustered on the départment level for all models. ${ }^{* *}$ denote $p<0.01{ }^{* *} p<0.05$, and ${ }^{*}$ $p<0.1$. The number of post offices in 1792 excludes that of Paris.

This interaction model addresses the endogeneity concern that postal expansion was determined by the location of the minority. First, it finds strong effects of postal expansion. It exhibits no significant impact, due to the lack of variation in the post office indicator as shown in Figure 6. By contrast, as variability increases the interaction is negative and significant at $600 \mathrm{~km}$ and $800 \mathrm{~km}$, suggesting that where post offices are built in the countryside, proximity reduces those who speak languages other than France. This result makes sense, as Paris would start installing staging posts in its proximity. Given the relatively short distances, people would regularly use French. From the perspective of the political center, the post as state capacity is expected to matter more in distant locales where the capital is unable to bring about direct rule. If the minority location drives the location of post offices, Models 3 and 4 of Table 5 should bear no significant effects in the interaction as few post offices are expected to be built. Overall, this evidence is compatible with one of the political goals with which Louis XI decided to built posts in the mid-fifteenth century-that the institution would play a role of consolidating authority by the French.

In the next section, I incorporate outside influence to see if the persistence of non-French speak- 
ers is determined by factors inside or outside France.

\section{The impact of outside factors}

I consider the impact of extra-France factors that might affect the consolidation of authority. The estimation examines major ones including interstate conflict, the spread of Protestantism, and the German imperial post. The last one is of particular interest given that access to post offices in France has a positive impact. The German post in the early sixteenth century provided an extended service to a few French cities including Paris and carried letters for nongovernmental purposes. ${ }^{19}$ The following equation summarizes the estimation:

Autonomy $_{i d}=\alpha_{3}+\beta_{3}$ Distance from Paris $_{i d}+$

$\theta_{3}$ Distance from the post office in $1559 / 1690 / 1792_{i d}+$

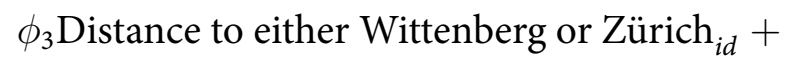

$\rho_{3}$ Distance to the nearest German imperial post ${ }_{i d}+$

$\psi_{3}$ Distance to conflict location, averaged between 1400 and $1700_{i d}+$ $\gamma_{3} X_{i d}+\epsilon_{i d}$

\footnotetext{
${ }^{19}$ For estimation I remove the observations of Paris and of Zürich, because the distance-to-Paris variable already exists and the distance to Zürich is covered by the distance variable on the impact of the Protestant Reformation.
} 
Table 6: OLS outputs of the impact of outside factors on the consolidation of authority in France.

\begin{tabular}{|c|c|c|c|c|c|c|c|}
\hline \multirow[t]{2}{*}{ Dependent variable } & \multicolumn{7}{|c|}{ Proportion of non-French-speaking communes } \\
\hline & (1) & $(2)$ & (3) & (4) & (5) & $(6)$ & $(7)$ \\
\hline Log distance to Paris & $\begin{array}{l}0.158^{* *} \\
(0.077)\end{array}$ & $\begin{array}{l}0.160^{* *} \\
(0.080)\end{array}$ & $\begin{array}{r}0.142^{*} \\
(0.082)\end{array}$ & $\begin{array}{l}0.178^{* *} \\
(0.084)\end{array}$ & $\begin{array}{l}0.143^{*} \\
(0.080)\end{array}$ & $\begin{array}{c}0.142^{*} \\
(0.084)\end{array}$ & $\begin{array}{c}0.166^{*} \\
(0.085)\end{array}$ \\
\hline Log distance to Wittenberg or Zürich & $\begin{array}{l}0.260^{* *} \\
(0.113)\end{array}$ & & & $\begin{array}{l}0.440^{* * *} \\
(0.141)\end{array}$ & & $\begin{array}{l}0.475^{* * *} \\
(0.141)\end{array}$ & $\begin{array}{l}0.424^{* * *} \\
(0.132)\end{array}$ \\
\hline Log distance to German imperial post & & $\begin{array}{c}0.027 \\
(0.058)\end{array}$ & & $\begin{array}{r}-0.113^{*} \\
(0.058)\end{array}$ & $\begin{array}{c}0.017 \\
(0.061)\end{array}$ & $\begin{array}{c}-0.146^{* *} \\
(0.057)\end{array}$ & $\begin{array}{l}-0.161^{* * *} \\
(0.056)\end{array}$ \\
\hline $\begin{array}{l}\text { Log distance to conflict location } \\
\text { averaged, } 1400-1700\end{array}$ & & & $\begin{array}{c}0.043 \\
(0.053)\end{array}$ & & $\begin{array}{c}0.034 \\
(0.055)\end{array}$ & $\begin{array}{c}0.077 \\
(0.060)\end{array}$ & $\begin{array}{c}0.080 \\
(0.059)\end{array}$ \\
\hline $\begin{array}{l}\text { Log distance to post offices } \\
\quad \text { in } 1559\end{array}$ & $\begin{array}{c}0.026 \\
(0.017)\end{array}$ & $\begin{array}{c}0.024 \\
(0.017)\end{array}$ & $\begin{array}{c}0.023 \\
(0.016)\end{array}$ & $\begin{array}{c}0.018 \\
(0.016)\end{array}$ & $\begin{array}{c}0.025 \\
(0.016)\end{array}$ & $\begin{array}{c}0.018 \\
(0.016)\end{array}$ & $\begin{array}{c}0.018 \\
(0.015)\end{array}$ \\
\hline in 1690 & $\begin{array}{r}-0.006 \\
(0.016)\end{array}$ & $\begin{array}{c}0.005 \\
(0.016)\end{array}$ & $\begin{array}{c}0.006 \\
(0.016)\end{array}$ & $\begin{array}{r}-0.001 \\
(0.016)\end{array}$ & $\begin{array}{c}0.004 \\
(0.016)\end{array}$ & $\begin{array}{r}-0.002 \\
(0.016)\end{array}$ & $\begin{array}{r}-0.001 \\
(0.016)\end{array}$ \\
\hline in 1792 & $\begin{array}{l}0.050^{* *} \\
(0.022)\end{array}$ & $\begin{array}{c}0.055^{* *} \\
(0.022)\end{array}$ & $\begin{array}{l}0.055^{* *} \\
(0.022)\end{array}$ & $\begin{array}{l}0.054^{* *} \\
(0.022)\end{array}$ & $\begin{array}{c}0.054^{* *} \\
(0.023)\end{array}$ & $\begin{array}{l}0.051^{* *} \\
(0.022)\end{array}$ & $\begin{array}{l}0.064^{* * *} \\
(0.024)\end{array}$ \\
\hline $\begin{array}{l}\text { Log distance to border } \\
\text { averaged, 1400-1800 }\end{array}$ & $\begin{array}{r}-0.080^{*} \\
(0.043)\end{array}$ & $\begin{array}{r}-0.044 \\
(0.045)\end{array}$ & $\begin{array}{r}-0.037 \\
(0.037)\end{array}$ & $\begin{array}{r}-0.071^{*} \\
(0.043)\end{array}$ & $\begin{array}{r}-0.043 \\
(0.046)\end{array}$ & $\begin{array}{r}-0.070^{*} \\
(0.042)\end{array}$ & \\
\hline $\begin{array}{l}\text { Log distance to coast } \\
\text { averaged, } 1400-1800\end{array}$ & $\begin{array}{l}0.077^{* *} \\
(0.031)\end{array}$ & $\begin{array}{c}0.037 \\
(0.026)\end{array}$ & $\begin{array}{c}0.025 \\
(0.027)\end{array}$ & $\begin{array}{l}0.089^{* * *} \\
(0.032)\end{array}$ & $\begin{array}{c}0.029 \\
(0.028)\end{array}$ & $\begin{array}{l}0.076^{* *} \\
(0.033)\end{array}$ & $\begin{array}{r}0.060^{*} \\
(0.032)\end{array}$ \\
\hline Controls & $\checkmark$ & $\checkmark$ & $\checkmark$ & $\checkmark$ & $\checkmark$ & $\checkmark$ & $\checkmark$ \\
\hline Observations & 214 & 214 & 214 & 214 & 214 & 214 & 214 \\
\hline
\end{tabular}

Notes: Robust standard errors clustered on the départment level for all models. ${ }^{* *}$ denote $p<0.01,{ }^{* *} p<0.05$, and ${ }^{\star}$ $p<0.1$.

Table 6 documents the impact of outside factors on the consolidation of authority. The access to the German imperial post is positive when included alone among the outside factors (Model 2) or combined with the distance to conflict location (Model 5). It turns negative and significant when the Protestant effect is added, suggesting that proximity to the German postal service would reduce the use of non-French tongues but only through the Protestant channel. The conflict variable is not systematically linked. The Protestant Reformation is the only one among the outside factors that exhibits consistent results. The positive coefficients mean that the more distant, the more likely French people are to use non-French tongues. I discuss this finding more below.

When outside influence is included, the distance to Paris remains positive and significant across the models. Its magnitude drops by 14.5 percent in a fully-specified model (Model 6) compared to Model 7 of Table 4. These results may suggest that one account for outside factors in correctly estimating the impact of geography within country. To test this idea, I omit the distance-to-border 
variable. It is reasonable not to control for it because, unlike coastal borders that are easily delimited, there were no "hard" borders everywhere at the time in terms of customs or passport control. Model 7 of Table 6 presents this result. It finds that the magnitude of the distance-to-Paris variable rebounds to that of Model 7 in Table 4. At the same time, the distance from 1792 post offices remains positive. These results suggest that outside factors do not systematically interfere with the French attempt to extent authority throughout country.

This result also addresses the second concern of endogeneity that non-French speakers in the countryside can retain their distinct cultural attributes because they are closer to, and influenced by, foreign countries. If this channel drives the the persistence of non-French speakers, the distanceto-Paris variable is expected to turn not significant, as is the proximity to the 1792 post office. At the same time, foreign determinants such as the distance to the German imperial post should be positively linked to the outcome variable, because the German system allowed non-German customers and delivered to neighboring destinations in today's Italy, Belgium, Austria, and Spain. Table 4 documents evidence to the contrary. This finding is reassuring in that the hypothesis that outside factors determine the extent to which non-French-speaking communities remain is unlikely.

To return to the significant effect of Protestantism, it seems that it is confounded by the distance to the coast. Table 6 indicates that the distance to the border or coast turns significant when the Protestantism variable is included. To tease out the relationship between these factors, Table 7 reestimates the impact of the Protestant Reformation. It finds that when the distance to the border or coast is absent, the Protestantism effect is not significant (Model 1). It is closely linked to the distance to the coast as its magnitude rises substantially and turns significant. This suggests that the significant effect of Protestantism is likely to be confounded by the distance to the coast. 
Table 7: OLS outputs of the relationship between Protestantism and the distances to coast or border.

\begin{tabular}{lcccc}
\hline \multicolumn{1}{c}{ Dependent variable } & \multicolumn{5}{c}{ Proportion of non-French-speaking communes } \\
& $(1)$ & $(2)$ & $(3)$ & $(4)$ \\
\hline Log distance to Paris & $0.166^{* *}$ & $0.145^{*}$ & $0.185^{* *}$ & $0.158^{* *}$ \\
& $(0.076)$ & $(0.077)$ & $(0.078)$ & $(0.077)$ \\
Log distance to Wittenberg or Zürich & 0.098 & 0.135 & $0.176^{*}$ & $0.260^{* *}$ \\
& $(0.082)$ & $(0.090)$ & $(0.097)$ & $(0.113)$ \\
Log distance to post offices & $0.027^{*}$ & 0.026 & $0.028^{*}$ & 0.026 \\
$\quad$ in 1559 & $(0.016)$ & $(0.017)$ & $(0.015)$ & $(0.017)$ \\
in 1690 & -0.004 & -0.005 & -0.005 & -0.006 \\
& $(0.016)$ & $(0.016)$ & $(0.016)$ & $(0.016)$ \\
$\quad$ in 1792 & $0.058^{* *}$ & $0.047^{* *}$ & $0.064^{* *}$ & $0.050^{* *}$ \\
& $(0.022)$ & $(0.022)$ & $(0.025)$ & $(0.022)$ \\
Log distance to border & & -0.051 & & $-0.080^{*}$ \\
$\quad$ averaged, 1400-1800 & & $(0.040)$ & & $(0.043)$ \\
Log distance to coast & & & $0.058^{*}$ & $0.077^{* *}$ \\
$\quad$ averaged, 1400-1800 & & & $(0.031)$ & $(0.031)$ \\
& $\checkmark$ & $\checkmark$ & $\checkmark$ & $\checkmark$ \\
Controls & 214 & 214 & 214 & 214 \\
Observations & & & \\
\hline
\end{tabular}

Notes: Robust standard errors clustered on the départment level for all models. ${ }^{* *}$ denote $p<0.01{ }^{* *} p<0.05$, and ${ }^{*}$ $p<0.1$.

Overall, three findings stand out. First, few major outside factors systematically explain the persistence of incomplete authority in early-modern France. Proximity to the German imperial post has a strong impact on reducing the use of non-French tongues, but it does so when the effect of Protestantism is considered. Second, France did not develop, or was unable to develop, capacity to impose rule on language, as the distance from Paris remains robust. In an era without access to reliable transportation (i.e., the railway), the distance from the capital constitutes a constant challenge to direct rule. Finally, sovereignty seemed incomplete throughout the pre-modern period. Foreign influence does not seem to affect systematically the development of state capacity in contrast to the hypothesis on a contemporary context in Melissa Lee (2018). The French state had the will to overcome the challenge of geographical distance and expand the scope of direct rule by building postal offices, but the effort seems insufficient. As Weber (1976, ch. 15) points out, the process of implementing control over the population was a "painfully slow" one. 


\section{Conclusion}

This paper explores the impact of the postal system in early-modern Europe on the development of state authority. The institution was designed not only to facilitate communication between the political center and far-flung areas within country but also to bring about political order. My analysis finds that with respect to the state's control over language, postal expansion helped but geographical distance remained a challenge throughout this period. The findings of this paper yield two broader implications. First, the state-building literature suggests that historically Europe faced few geographical constraints, especially when compared to the process in regions like Africa and Latin America. One reason is that Europe had higher population density in cities so that the state-directed large-scale movement of people due to war was less costly. But the consolidation of state authority is another story that has has not been widely investigated. My study provides additional support for the argument that geographical scale played an important role in limiting direct rule among European polities (Stasavage 2010). Second, the recent scholarship focusing on post offices and transport as sources of economic growth is situated in the modern context (Donaldson 2018; Rogowski et al. Forthcoming). It is possible that the networks of these communications technologies are based on

the preexisting ones built in the prior period. As these works demonstrate, the pre-modern postal system also substantially reduced transaction costs in communications on both political and economic dimensions. If the modern transport infrastructure contributes to growth, this study makes a bridge by exploring the impact of the pre-modern postal institution. 


\section{References}

Acemoglu, Daron, Simon Johnson, and James A. Robinson. 2005. "Institutions as a Fundamental Cause of Long-Run Growth". In Handbook of Economic Growth, ed. Philippe Aghion and Steven N. Durlauf. Vol. 1A. New York: Elsevier, pp. 385-472.

Åhlfeldt, Johan. 2015. "Digital Atlas of the Roman Empire.”.

URL: http: //dare.ht.lu.se/

Allen, E. John B. 1972. Post and Courier Service in the Diplomacy of Early Modern Europe. The Hague: Marinus Nijhoff.

Andrews, Matt, Lant Pritchett, and Michael Woolcock. 2017. Building State Capability: Evidence, Analysis, Action. New York: Oxford University Press.

Arbellot, Guy, and Bernard Lepetit. 1987. Atlas de la Révolution française. Vol. 1: Routes et communications. Paris: École des Hautes Études en Sciences Sociales.

Bairoch, Paul, Jean Batou, and Pierre Chévre. 1988. La Population des Villes Européennes de 800 à 1850: Banque de Données et Analyse Sommaire des Résultats (The Population of European Cities from 800 to 1850: Data Bank and Short Summary of Results). Genéve: Librairie Droz.

Becquey, François-Louis. 1820. Rapport au Roi sur la Navigation Intérieure de la France. Paris: Imprimerie Royale.

Behringer, Wolfgang. 1990. Thurn und Taxis: Die Geschichte ihrer Post und ihrer Unternehmen. München: Piper Verlag.

Behringer, Wolfgang. 2006. “Communications Revolutions: A Historiographical Concept.” German History 24(3): 333-74.

Beik, William. 2005. “The Absolutism of Louis XIV as Social Collaboration.” Past and Present 188: 195-224.

Bell, David A. 2001. The Cult of the Nation in France: Inventing Nationalism, 1680-1800. Cambridge, MA: Harvard University Press.

Bensel, Richard Franklin. 1990. Yankee Leviathan: The Origins of Central State Authority in America, 1859-1877. New York: Cambridge University Press.

Besley, Timothy, and Torsten Persson. 2009. “The Origins of State Capacity: Property Rights, Taxation, and Politics." American Economic Review 99(4): 1218-44.

Besley, Timothy, and Torsten Persson. 2010. “State Capacity, Conflict, and Development." Econometrica 78(1): 1-34.

Blockmans, Wim P. 1976. "Le Régime Représentatif en Flandre dans le Cadre Européen au bas Moyen Age avec un Projet d'Application des Ordinateurs". In Album Elémer Màlyusz: Études Présentées à la Commission Internationale pour l'Histoire des Assemblées d'États LXI. (Studies Presented to the International Commission for the History of Representative and Parliamentary Institutions.). Bruxelles: Les Éditions de la Librairie encyclopédique, pp. 211-45. 
Boissière, Aurélie. 2016. Atlas de l'histoire de France, 481-2005. Saint-Just-la-Pendue: Belin.

Bosker, Maarten, Eltjo Buringh, and Jan Luiten van Zanden. 2013. "From Baghdad to London: Unraveling Urban Development in Europe, the Middle East, and North Africa, 800-1800." Review of Economics and Statistics 95(4): 1418-37.

Bouchot, Henri. 1890. The Book: Its Printers, Illustrators, and Binders, from Gutenberg to the Present Time. London: H. Grevel \& Co.

Brayshay, Mark, Philip Harrison, and Brian Chalkley. 1998. "Knowledge, Nationhood and Governance: The Speed of the Royal Post in Early-modern England." Journal of Historical Sociology 24(3): $265-88$.

Burke, Peter. 2004. Languages and Communities in Early Modern Europe. Cambridge: Cambridge University Press.

Campbell, Peter R. 2012. "Absolute Monarchy”. In The Oxford Handbook of the Ancien Régime, ed. William Doyle. New York: Oxford University Press, pp. 11-38.

Cantoni, Davide, and Noam Yuchtman. 2014. "Medieval Universities, Legal Institutions, and the Commercial Revolution." Quarterly Journal of Economics 129(2): 823-87.

Clair, Colin. 1976. A History of European Printing. New York: Academic Press.

Conner, Philip. 2001. “A Provincial Perspective: Protestant Print Culture in Southern France”. In The Sixteenth-Century French Religious Book, ed. Andrew Pettegree, Paul Nelles, and Philip Conner. Aldershot: Ashgate, pp. 286-302.

Darby, H.C., and Harold Fullard, eds. 1970. The New Cambridge Modern History. Vol. 14: Atlas. Cambridge: Cambridge University Press.

Dincecco, Mark. 2015. “The Rise of Effective States in Europe." Journal of Economic History 75(3): 901-18.

Dincecco, Mark, and Massimiliano Gaetano Onorato. 2016. "Military Conflict and the Rise of Urban Europe." Journal of Economic Growth 21(3): 259-82.

Dittmar, Jeremiah E., and Ralf R. Meisenzahl. 2016. "State Capacity and Public Goods: Institutional Change, Human Capital, and Growth in Early Modern Germany." Mimeo.

Donaldson, Dave. 2018. "Railroads of the Raj: Estimating the Impact of Transportation Infrastructure." American Economic Review 108(4-5): 899-934.

Elliott, J.H. 1992. “A Europe of Composite Monarchies.” Past and Present 137: 48-71.

Epstein, Stephan R., ed. 2000. Freedom and Growth: The Rise of States and Markets in Europe 13001750. London: Routledge.

Ertman, Thomas. 1997. Birth of the Leviathan: Building States and Regimes in Medieval and Early Modern Europe. New York: Cambridge University Press. 
Febvre, Lucien, and Henri-Jean Martin. 1976. The Coming of the Book: The Impact of Printing, 1450-1800. 3rd ed. London: Verso.

Frijhoff, Willem. 1996. "Patterns". In A History of the University in Europe, ed. Hilde de RidderSymoens. Vol. 2: Universities in Early Modern Europe. Cambridge: Cambridge University Press, pp. 43-110.

Fukuyama, Francis. 2011. The Origins of Political Order: From Prehuman Times to the French Revolution. New York: Farrar, Straus and Giroux.

GLOBE Task Team and others. 1999. “The Global Land One-kilometer Base Elevation (GLOBE) Digital Elevation Model...

URL: http://www.ngdc.noaa.gov/mgg/topo/globe.html

Gorski, Philip S. 2003. The Disciplinary Revolution: Calvinism and the Rise of the State in Early Modern Europe. Chicago: University of Chicago Press.

Hammond, Nicholas G.L., ed. 1981. Atlas of the Greek and Roman World in Antiquity. Park Ridge, NJ: Noyes Press.

Herbst, Jeffrey. 2000. States and Power in Africa: Comparative Lessons in Authority and Control. Princeton: Princeton University Press.

Jaillot, Alexis-Hubert. 1690. "Carte particulière des postes de France.”.

URL: https: //www.wdl.org/en/item/14770/

Johnson, Noel D. 2006. "Banking on the King: The Evolution of the Royal Revenue Farms in Old Regime France." Journal of Economic History 66(4): 963-91.

Johnson, Noel D., and Mark Koyama. 2014. "Tax Farming and the Origins of State Capacity in England and France." Explorations in Economic History 51(1): 1-20.

Johnson, Noel D., and Mark Koyama. 2017. "States and Economic Growth: Capacity and Constraints." Explorations in Economic History 64: 1-20.

Kiser, Edgar, and April Linton. 2001. "Determinants of the Growth of the State: War and Taxation in Early Modern France and England." Social Forces 80(2): 411-48.

Kiser, Edgar, and April Linton. 2002. "The Hinges of History: State-Making and Revolt in Early Modern France." American Sociological Review 67(6): 889-910.

Koenigsberger, H.G. 1987. Early Modern Europe, 1500-1789. London: Longman.

Lee, Melissa M. 2018. “The International Politics of Incomplete Sovereignty: How Hostile Neighbors Weaken the State.” International Organization 72(2): 283-315.

Michalopoulos, Stelios. 2012. “The Origins of Ethnolinguistic Diversity." American Economic Review 102(4): 1508-39. 
Michalopoulos, Stelios, and Elias Papaioannou. 2013. "Pre-Colonial Ethnic Institutions and Contemporary African Development." Econometrica 81(1): 113-52.

Michalopoulos, Stelios, and Elias Papaioannou. 2014. "National Institutions and Subnational Development in Africa." Quarterly Journal of Economics 129(1): 151-213.

Minahan, James B. 2000. One Europe, Many Nations: A Historical Dictionary of European National Groups. Westport, CO: Greenwood Press.

Mylonas, Harris. 2012. The Politics of Nation-Building: Making Co-Nationals, Refugees and Minorities. New York: Cambridge University Press.

Nexon, Daniel H. 2009. The Struggle for Power in Early Modern Europe: Religious Conflict, Dynastic Empires, and International Change. Princeton: Princeton University Press.

Nunn, Nathan, and Diego Puga. 2012. "Ruggedness: The Blessing of Bad Geography in Africa." Review of Economics and Statistics 94(1): 20-36.

Nüssli, Christos. 2011. "Euratlas.”.

URL: http: //www. euratlas.com/about.html

Olsson, Ola, and Gustav Hansson. 2011. "Country Size and the Rule of Law: Resuscitating Montesquieu." European Economic Review 55(5): 613-29.

Perlman, Elisabeth Ruth, and Steven Sprick Schuster. 2016. "Delivering the Vote: The Political Effect of Free Mail Delivery in Early Twentieth Century America." Journal of Economic History 76(3): 769-802.

Pettegree, Andrew. 2007. The French Book and the European Book World Renaissance. Leiden and Boston: Brill.

Pettegree, Andrew. 2010. The Book in the Renaissance. New Haven: Yale University Press.

Pettegree, Andrew. 2014. The Invention of News: How the World Came to Know about Itself. New Haven: Yale University Press.

Pfaff, Steven, and Katie E. Corcoran. 2012. "Piety, Power, and the Purse: Religious Economies Theory and Urban Reform in the Holy Roman Empire." Journal for the Scientific Study of Religion 51(4): 757-76.

Pleiades. 2015.

URL: http://pleiades.stoa.org/home

Poggi, Gianfranco. 1978. The Development of the Modern State: A Sociological Introduction. Stanford: Stanford University Press.

Raj, Prateek. 2018. "Origins of Impersonal Markets in Commercial and Communication Revolutions of Europe." Mimeo. 
Raymond, Joad, and Noah Moxham, eds. 2016. News Networks in Early Modern Europe. Leiden and Boston: Brill.

Reske, Christoph. 2007. Die Buchdrucker des 16. und 17. Jahrhunderts im deutschen Sprachgebiet. Auf der Grundlage des gleichnamigen Werkes von Josef Benzing. Wiesbaden: Harrassowitz.

Riley, Shawn J., Stephen D. DeGloria, and Robert Elliot. 1999. "A Terrain Ruggedness Index That Quantifies Topographic Heterogeneity." Intermountain Journal of Sciences 6(1-4): 23-7.

Rogowski, Jon C., John Gerring, Matthew Maguire, and Lee Cojocaru. Forthcoming. "Public Infrastructure and Economic Development: Evidence from Postal Systems." American Political Science Review.

Rubin, Jared. 2014. "Printing and Protestants: An Empirical Test of the Role of Printing in the Reformation." Review of Economics and Statistics 96(2): 270-86.

Rüegg, Walter, ed. 2011. A History of the University in Europe. Vol. 1-4. Cambridge: Cambridge University Press.

Schobesgerger, Nikolaus, Paul Arblaster, Mario Infeslise, André Belo, Noah Moxham, Carmen Espejo, and Joad Raymond. 2016. "European Postal Networks". In News Networks in Early Modern Europe, ed. Joad Raymond and Noah Moxham. Vol. 47 of the Library of the Written Word: The Handpress World, vol. 35. Leiden and Boston: Brill, pp. 19-63.

Scott, James C. 1998. Seeing Like a State: How Certain Schemes to Improve the Human Condition Have Failed. New Haven: Yale University Press.

Simons, Gary F., and Charles D. Fennig, eds. 2018. Ethnologue: Languages of the World. 21st ed. Dallas, TX: SIL International.

URL: www . ethnologue.com/

Spruyt, Hendrik. 1994. The Sovereign State and Its Competitors: An Analysis of Systems Change. Princeton: Princeton University Press.

Stasavage, David. 2010. "When Distance Mattered: Geographic Scale and the Development of European Representative Assemblies." American Political Science Review 104(4): 625-43.

Strayer, Joseph R. 1970. On the Medieval Origins of the Modern State. Princeton: Princeton University Press.

Swann, Julian. 2012. "Parlements and Provincial Estates". In The Oxford Handbook of the Ancien Régime, ed. William Doyle. New York: Oxford University Press, pp. 93-108.

Talbert, Richard J.A., ed. 2000. Barrington Atlas of the Greek and Roman World. Princeton: Princeton University Press.

Tilly, Charles. 1992. Coercion, Capital, and European States, AD 990-1992. Malden, MA: Blackwell. 
Walsby, Malcolm. 2011a. "The Vanishing Press: Printing in Provincial France in the Early Sixteenth Century". In The Book Triumphant: Print in Transition in the Sixteenth and Seventeenth Centuries., ed. Malcolm Walsby and Graeme Kemp. Vol. 15 of the Library of the Written Word: The Handpress World, vol. 9. Leiden and Boston: Brill, pp. 97-111.

Walsby, Malcolm. 2011b. The Printed Book in Brittany, 1484-1600. Leiden and Boston: Brill.

Weber, Eugen. 1976. Peasants into Frenchmen: The Modernization of Rural France, 1870-1914. Stanford: Stanford University Press.

Wimmer, Andreas. 2016. "Is Diversity Detrimental? Ethnic Fractionalization, Public Goods Provision, and the Historical Legacies of Stateness." Comparative Political Studies 49(11): 1407-45.

Wimmer, Andreas. 2018. Nation Building: Why Some Countries Come Together While Others Fall Apart. Princeton: Princeton University Press. 


\section{Appendix for "Ethnic Autonomy"}

August 15, 2019

\section{Contents}

1 Original Maps of Post Offices in France $\quad$ A2

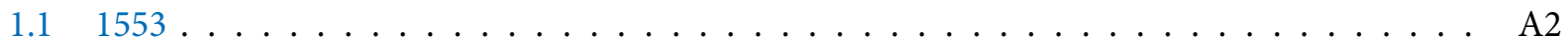

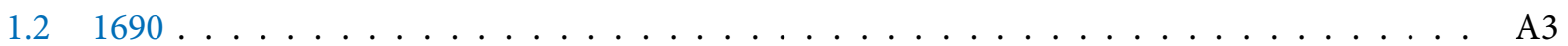

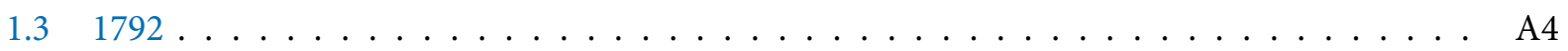

2 Estimation Results $\quad$ A5

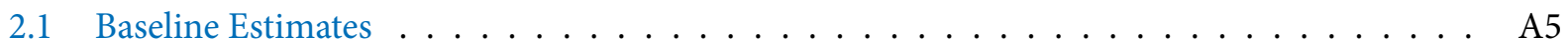

2.2 Estimates of Impact of Post Offices $\ldots \ldots \ldots \ldots \ldots \ldots \ldots \ldots \ldots \ldots \ldots$

2.3 Estimates of Impact of Outside Influence $\ldots \ldots \ldots \ldots \ldots \ldots \ldots \ldots$ 


\section{Original Maps of Post Offices in France}

\subsection{3}

Figure A1 shows the distribution of the post offices in France in 1553. It is drawn by cartographer Boissière, Aurélie in Atlas de l'histoire de France, 481-2005 (2016).

Figure A1: Location of post offices in France in 1553.

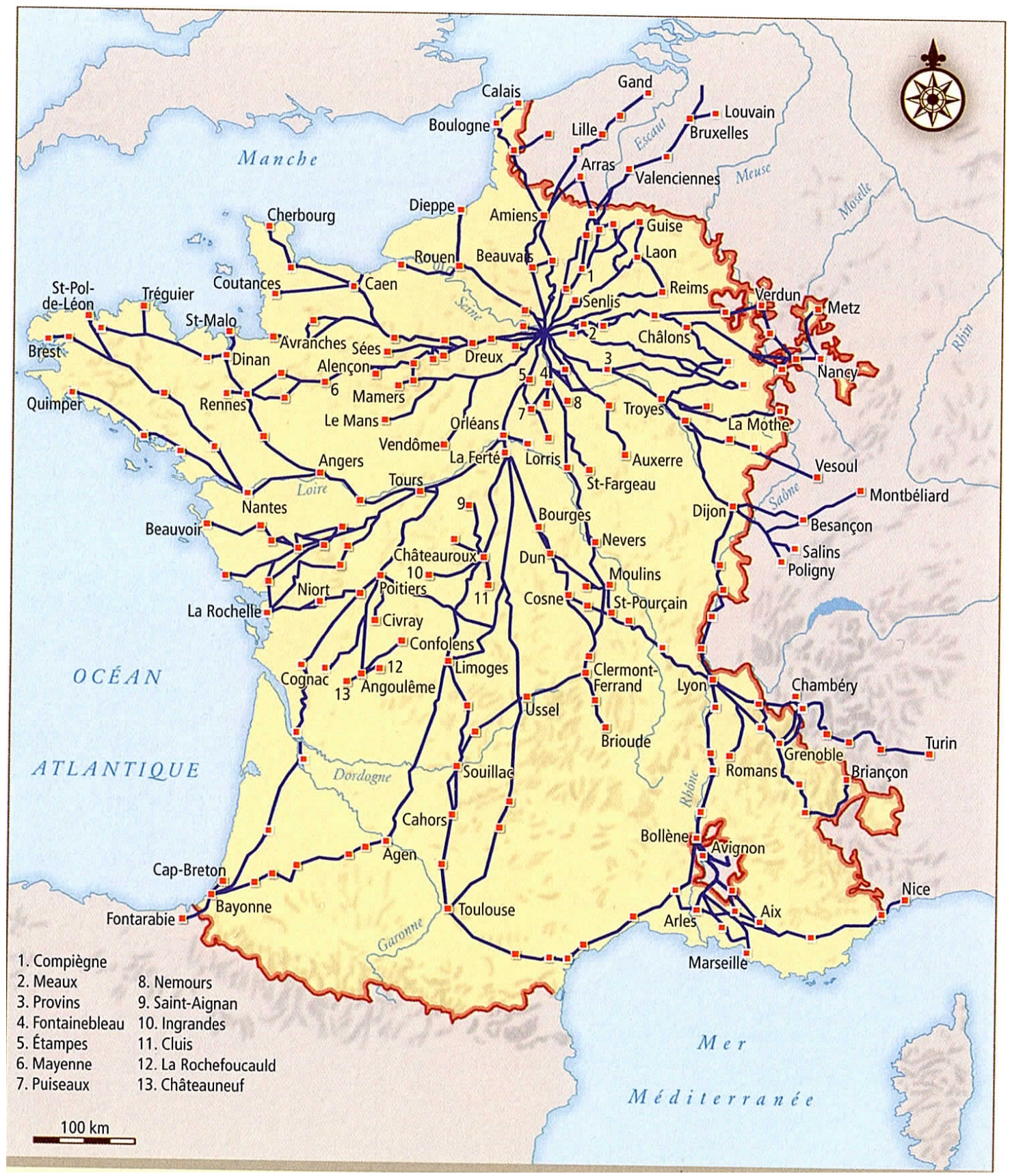




\subsection{0}

Figure A2 exhibits the location of the relay stations of the French post in 1690. Titled "Carte particulière des postes de France," it is drawn by Alexis-Hubert Jaillot. It supersedes the more famous 1632 "Carte géographique des Postes qui traversent la France" drawn by Nicolas Sanson. The map is available online as part of the World Digital Library project of the U.S. Library of Congress.

\section{Figure A2: Location of post offices in France in 1690.}

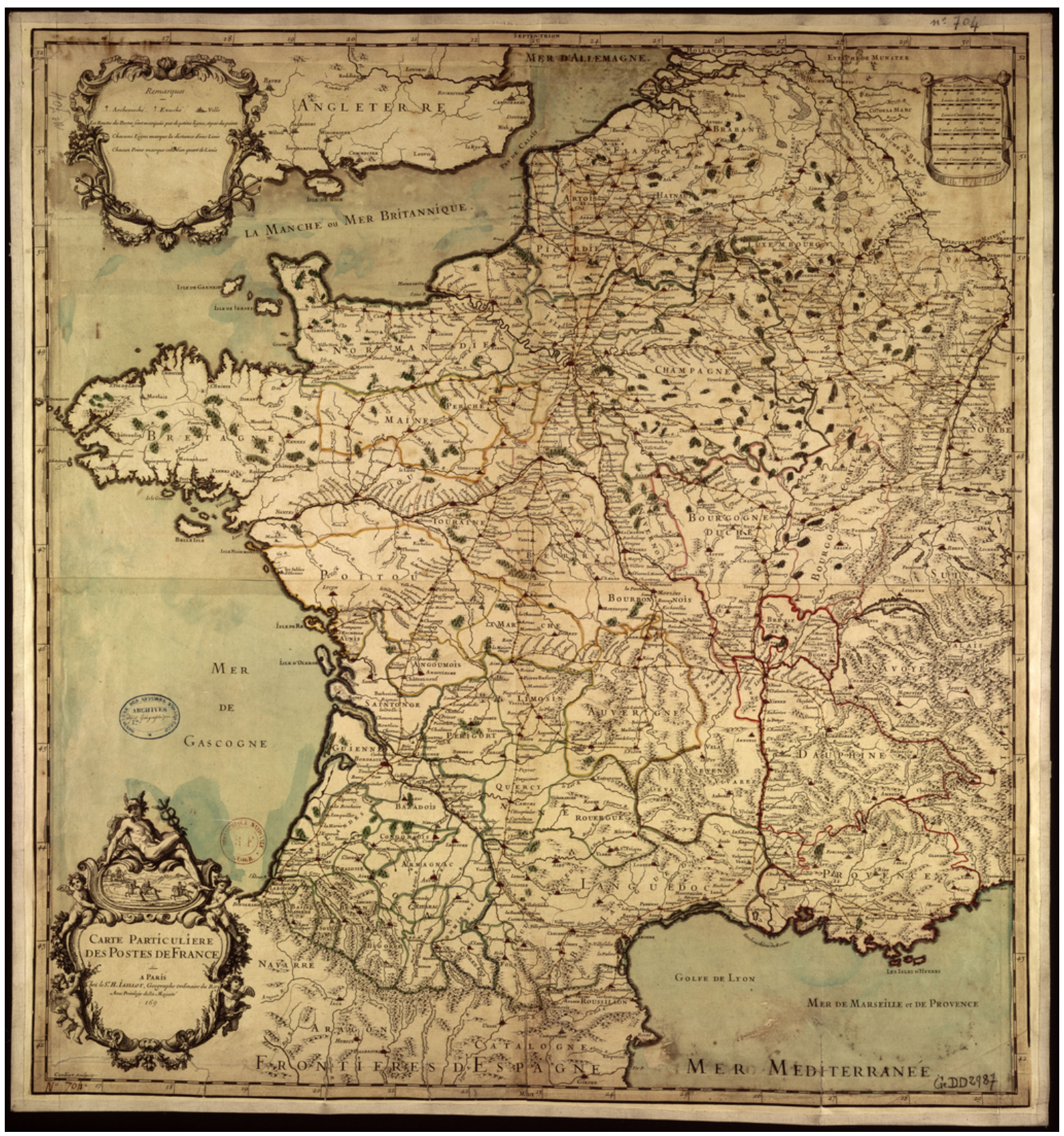




\section{$1.3 \quad 1792$}

Figure A3 presents the distribution of France's post offices in 1792. It comes from Guy Arbellot and Bernard Lepetit in Atlas de la Révolution française, vol. 1: Routes et communications (1987). It is part of a 11-volume series on the French Revolution published by the École des Hautes Études en Sciences Sociales.

\section{Figure A3: Location of post offices in France in 1792.}

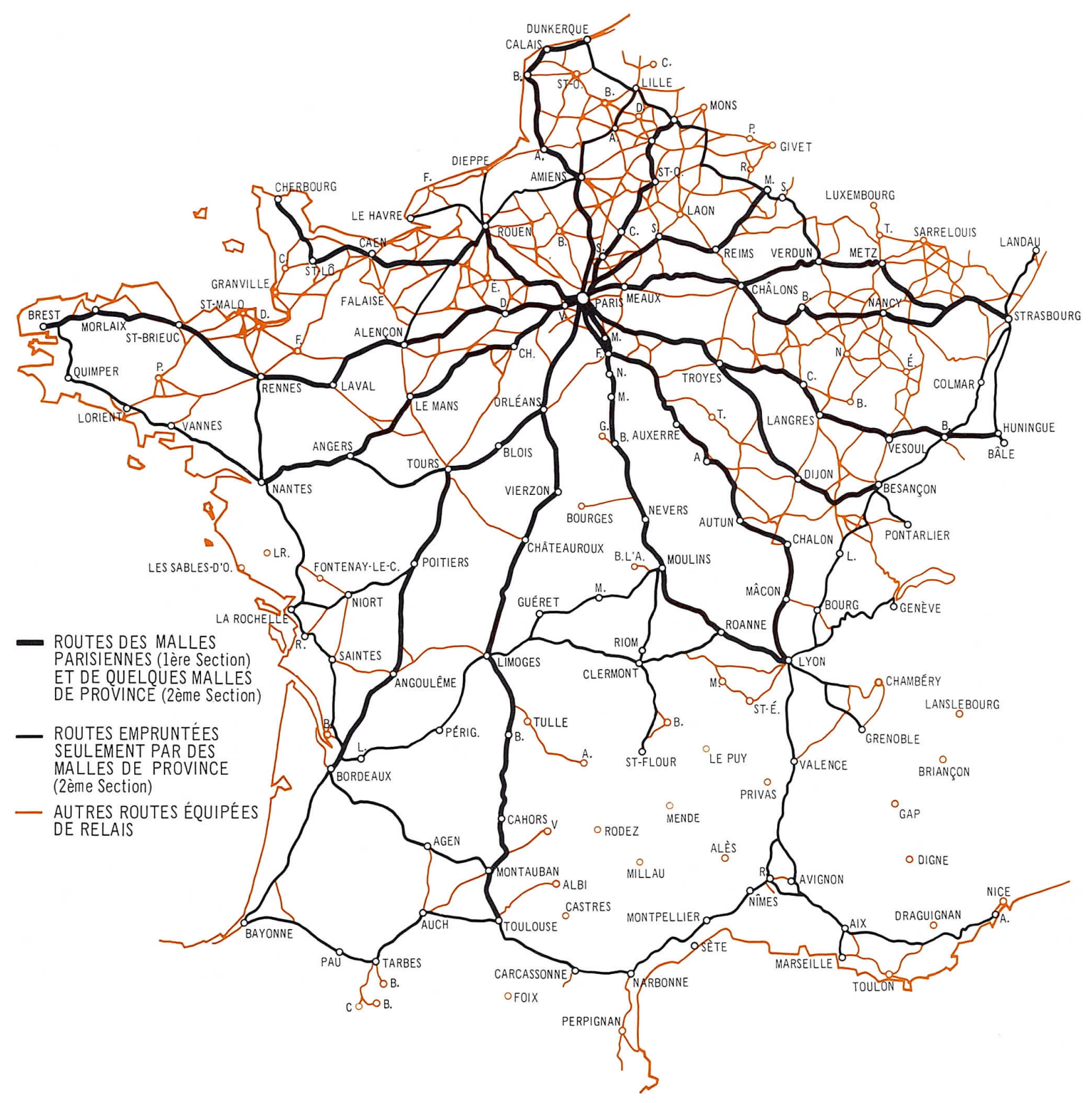




\section{Estimation Results}

\subsection{Baseline Estimates}

Table A1 reports the full result of Table $\mathrm{x}$ of the main text.

Table A1: OLS outputs of the impact of within-country factors on the consolidation of authority in France.

\begin{tabular}{|c|c|c|c|c|c|c|}
\hline \multirow[t]{2}{*}{ Dependent variable } & \multicolumn{6}{|c|}{ Proportion of non-French-speaking communes } \\
\hline & (1) & (2) & (3) & $(4)$ & $(5)$ & (6) \\
\hline Log distance to Paris & $\begin{array}{l}0.269^{* * *} \\
(0.075)\end{array}$ & $\begin{array}{l}0.196^{* *} \\
(0.087)\end{array}$ & $\begin{array}{l}0.234^{* * *} \\
(0.089)\end{array}$ & $\begin{array}{l}0.204^{* *} \\
(0.090)\end{array}$ & $\begin{array}{l}0.209^{* *} \\
(0.084)\end{array}$ & $\begin{array}{l}0.219^{* *} \\
(0.088)\end{array}$ \\
\hline $\begin{array}{l}\text { Log distance to border } \\
\text { averaged, } 1400-1800\end{array}$ & & $\begin{array}{c}-0.060 \\
(0.045)\end{array}$ & & $\begin{array}{c}-0.064 \\
(0.047)\end{array}$ & $\begin{array}{r}-0.082^{*} \\
(0.047)\end{array}$ & $\begin{array}{r}-0.051 \\
(0.044)\end{array}$ \\
\hline $\begin{array}{l}\text { Log distance to border } \times \\
\text { number of canals within } 50 \mathrm{~km}\end{array}$ & & & & & $\begin{array}{c}0.088 \\
(0.056)\end{array}$ & \\
\hline $\begin{array}{l}\text { Log distance to nearest coast } \\
\text { averaged, } 1400-1800\end{array}$ & & & $\begin{array}{c}0.015 \\
(0.033)\end{array}$ & $\begin{array}{c}0.021 \\
(0.028)\end{array}$ & $\begin{array}{c}0.029 \\
(0.025)\end{array}$ & $\begin{array}{c}0.004 \\
(0.028)\end{array}$ \\
\hline $\begin{array}{l}\text { Log distance to nearest coast } \times \\
\text { number of canals within } 50 \mathrm{~km}\end{array}$ & & & & & & $\begin{array}{c}0.037 \\
(0.030)\end{array}$ \\
\hline Elevation & & $\begin{array}{r}0.00003 \\
(0.0002)\end{array}$ & $\begin{array}{c}-0.00003 \\
(0.0003)\end{array}$ & $\begin{array}{r}-0.0001 \\
(0.0003)\end{array}$ & $\begin{array}{r}-0.0001 \\
(0.0003)\end{array}$ & $\begin{array}{r}-0.0001 \\
(0.0003)\end{array}$ \\
\hline Terrain ruggedness & & $\begin{array}{l}-0.001 \\
(0.0004)\end{array}$ & $\begin{array}{r}-0.0004 \\
(0.0004)\end{array}$ & $\begin{array}{r}-0.0004 \\
(0.0004)\end{array}$ & $\begin{array}{r}-0.0005 \\
(0.0004)\end{array}$ & $\begin{array}{r}-0.0004 \\
(0.0004)\end{array}$ \\
\hline Years provincial estates held & & $\begin{array}{c}0.001 \\
(0.0003)\end{array}$ & $\begin{array}{c}0.0004 \\
(0.0003)\end{array}$ & $\begin{array}{c}0.001^{*} \\
(0.0003)\end{array}$ & $\begin{array}{c}0.001^{*} \\
(0.0003)\end{array}$ & $\begin{array}{c}0.001 \\
(0.0003)\end{array}$ \\
\hline Weighted log population growth by 1850 & & $\begin{array}{c}-0.003 \\
(0.039)\end{array}$ & $\begin{array}{r}-0.005 \\
(0.040)\end{array}$ & $\begin{array}{c}-0.007 \\
(0.039)\end{array}$ & $\begin{array}{r}-0.009 \\
(0.038)\end{array}$ & $\begin{array}{r}-0.003 \\
(0.038)\end{array}$ \\
\hline Number of printing presses by 1700 & & $\begin{array}{r}-0.035 \\
(0.029)\end{array}$ & $\begin{array}{r}-0.037 \\
(0.030)\end{array}$ & $\begin{array}{r}-0.035 \\
(0.028)\end{array}$ & $\begin{array}{r}-0.030 \\
(0.028)\end{array}$ & $\begin{array}{r}-0.044 \\
(0.032)\end{array}$ \\
\hline Number of fair centers within $50 \mathrm{~km}$ & & $\begin{array}{c}0.032 \\
(0.095)\end{array}$ & $\begin{array}{c}0.029 \\
(0.098)\end{array}$ & $\begin{array}{c}0.044 \\
(0.092)\end{array}$ & $\begin{array}{c}0.030 \\
(0.093)\end{array}$ & $\begin{array}{c}0.042 \\
(0.093)\end{array}$ \\
\hline Number of canals within $50 \mathrm{~km}$ & & $\begin{array}{r}-0.053 \\
(0.039)\end{array}$ & $\begin{array}{r}-0.048 \\
(0.039)\end{array}$ & $\begin{array}{r}-0.054 \\
(0.038)\end{array}$ & $\begin{array}{r}-0.468^{*} \\
(0.261)\end{array}$ & $\begin{array}{r}-0.209 \\
(0.140)\end{array}$ \\
\hline Number of universities & & $\begin{array}{c}0.039 \\
(0.056)\end{array}$ & $\begin{array}{c}0.040 \\
(0.055)\end{array}$ & $\begin{array}{c}0.038 \\
(0.055)\end{array}$ & $\begin{array}{c}0.038 \\
(0.056)\end{array}$ & $\begin{array}{c}0.045 \\
(0.056)\end{array}$ \\
\hline Roman hub & & $\begin{array}{r}-0.021 \\
(0.053)\end{array}$ & $\begin{array}{r}-0.018 \\
(0.054)\end{array}$ & $\begin{array}{r}-0.022 \\
(0.053)\end{array}$ & $\begin{array}{r}-0.020 \\
(0.053)\end{array}$ & $\begin{array}{r}-0.013 \\
(0.052)\end{array}$ \\
\hline Roman road & & $\begin{array}{r}-0.009 \\
(0.083)\end{array}$ & $\begin{array}{r}-0.023 \\
(0.083)\end{array}$ & $\begin{array}{r}-0.011 \\
(0.083)\end{array}$ & $\begin{array}{r}-0.020 \\
(0.083)\end{array}$ & $\begin{array}{r}-0.011 \\
(0.082)\end{array}$ \\
\hline Years under Roman rule & & $\begin{array}{c}0.0001 \\
(0.0002)\end{array}$ & $\begin{array}{c}0.0002 \\
(0.0002)\end{array}$ & $\begin{array}{c}0.0001 \\
(0.0001)\end{array}$ & $\begin{array}{c}0.0002 \\
(0.0001)\end{array}$ & $\begin{array}{c}0.0001 \\
(0.0001)\end{array}$ \\
\hline Access to river & & $\begin{array}{c}-0.023 \\
(0.096)\end{array}$ & $\begin{array}{r}-0.037 \\
(0.095)\end{array}$ & $\begin{array}{c}-0.041 \\
(0.097)\end{array}$ & $\begin{array}{r}-0.037 \\
(0.097)\end{array}$ & $\begin{array}{r}-0.044 \\
(0.097)\end{array}$ \\
\hline Intercept & $\begin{array}{c}-1.264^{* * *} \\
(0.419)\end{array}$ & $\begin{array}{c}-0.584 \\
(0.600)\end{array}$ & $\begin{array}{c}-1.124^{* *} \\
(0.519)\end{array}$ & $\begin{array}{c}-0.693 \\
(0.645)\end{array}$ & $\begin{array}{c}-0.679 \\
(0.611)\end{array}$ & $\begin{array}{c}-0.760 \\
(0.630)\end{array}$ \\
\hline Observations & 214 & 214 & 214 & 214 & 214 & 214 \\
\hline
\end{tabular}

Notes: Robust standard errors clustered on the départment level for all models. ${ }^{\star * \star}$ denote $p<0.01,{ }^{\star *} p<0.05$, and ${ }^{\star} p<0.1$. 
Table A2: OLS outputs of the impact of within-country factors on the consolidation of authority in France.

\begin{tabular}{|c|c|c|c|c|c|c|}
\hline \multirow[t]{2}{*}{ Dependent variable } & \multicolumn{6}{|c|}{ Proportion of non-French-speaking populations } \\
\hline & $(1)$ & $(2)$ & (3) & $(4)$ & $(5)$ & $(6)$ \\
\hline Log distance to Paris & $\begin{array}{l}0.239^{* * *} \\
(0.068)\end{array}$ & $\begin{array}{l}0.177^{* *} \\
(0.080)\end{array}$ & $\begin{array}{l}0.213^{* *} \\
(0.082)\end{array}$ & $\begin{array}{l}0.184^{* *} \\
(0.082)\end{array}$ & $\begin{array}{l}0.190^{* *} \\
(0.076)\end{array}$ & $\begin{array}{l}0.197^{* *} \\
(0.080)\end{array}$ \\
\hline $\begin{array}{l}\text { Log distance to border } \\
\text { averaged, 1400-1800 }\end{array}$ & & $\begin{array}{r}-0.057 \\
(0.044)\end{array}$ & & $\begin{array}{r}-0.060 \\
(0.046)\end{array}$ & $\begin{array}{r}-0.080^{*} \\
(0.045)\end{array}$ & $\begin{array}{r}-0.049 \\
(0.042)\end{array}$ \\
\hline $\begin{array}{l}\text { Log distance to nearest border } \times \\
\text { number of canals within } 50 \mathrm{~km}\end{array}$ & & & & & $\begin{array}{l}0.101^{* *} \\
(0.050)\end{array}$ & \\
\hline $\begin{array}{l}\text { Log distance to coast } \\
\text { averaged, 1400-1800 }\end{array}$ & & & $\begin{array}{c}0.012 \\
(0.031)\end{array}$ & $\begin{array}{c}0.018 \\
(0.025)\end{array}$ & $\begin{array}{c}0.028 \\
(0.022)\end{array}$ & $\begin{array}{c}0.004 \\
(0.026)\end{array}$ \\
\hline $\begin{array}{l}\text { Log distance to nearest coast } \times \\
\text { number of canals within } 50 \mathrm{~km}\end{array}$ & & & & & & $\begin{array}{c}0.031 \\
(0.026)\end{array}$ \\
\hline Elevation & & $\begin{array}{r}-0.00001 \\
(0.0002)\end{array}$ & $\begin{array}{r}-0.0001 \\
(0.0002)\end{array}$ & $\begin{array}{r}-0.0001 \\
(0.0002)\end{array}$ & $\begin{array}{r}-0.0001 \\
(0.0002)\end{array}$ & $\begin{array}{r}-0.0001 \\
(0.0002)\end{array}$ \\
\hline Terrain ruggedness & & $\begin{array}{c}-0.0004 \\
(0.0003)\end{array}$ & $\begin{array}{c}-0.0003 \\
(0.0004)\end{array}$ & $\begin{array}{c}-0.0003 \\
(0.0004)\end{array}$ & $\begin{array}{c}-0.0004 \\
(0.0004)\end{array}$ & $\begin{array}{c}-0.0003 \\
(0.0004)\end{array}$ \\
\hline Years provincial estates held & & $\begin{array}{c}0.0004 \\
(0.0003)\end{array}$ & $\begin{array}{c}0.0002 \\
(0.0003)\end{array}$ & $\begin{array}{c}0.0004 \\
(0.0003)\end{array}$ & $\begin{array}{c}0.0004 \\
(0.0003)\end{array}$ & $\begin{array}{c}0.0004 \\
(0.0003)\end{array}$ \\
\hline Weighted log population growth by 1850 & & $\begin{array}{r}-0.006 \\
(0.035)\end{array}$ & $\begin{array}{c}-0.007 \\
(0.035)\end{array}$ & $\begin{array}{c}-0.010 \\
(0.034)\end{array}$ & $\begin{array}{c}-0.012 \\
(0.034)\end{array}$ & $\begin{array}{c}-0.006 \\
(0.034)\end{array}$ \\
\hline Number of printing presses by 1700 & & $\begin{array}{r}-0.037 \\
(0.027)\end{array}$ & $\begin{array}{r}-0.039 \\
(0.028)\end{array}$ & $\begin{array}{c}-0.036 \\
(0.027)\end{array}$ & $\begin{array}{r}-0.030 \\
(0.026)\end{array}$ & $\begin{array}{c}-0.044 \\
(0.029)\end{array}$ \\
\hline Number of fair centers within $50 \mathrm{~km}$ & & $\begin{array}{c}0.020 \\
(0.083)\end{array}$ & $\begin{array}{c}0.017 \\
(0.086)\end{array}$ & $\begin{array}{c}0.030 \\
(0.081)\end{array}$ & $\begin{array}{c}0.014 \\
(0.081)\end{array}$ & $\begin{array}{c}0.029 \\
(0.081)\end{array}$ \\
\hline Number of canals within $50 \mathrm{~km}$ & & $\begin{array}{r}-0.044 \\
(0.035)\end{array}$ & $\begin{array}{r}-0.040 \\
(0.035)\end{array}$ & $\begin{array}{r}-0.045 \\
(0.035)\end{array}$ & $\begin{array}{c}-0.518^{* *} \\
(0.234)\end{array}$ & $\begin{array}{r}-0.175 \\
(0.127)\end{array}$ \\
\hline Number of universities & & $\begin{array}{c}0.025 \\
(0.048)\end{array}$ & $\begin{array}{c}0.027 \\
(0.047)\end{array}$ & $\begin{array}{c}0.025 \\
(0.048)\end{array}$ & $\begin{array}{c}0.025 \\
(0.048)\end{array}$ & $\begin{array}{c}0.030 \\
(0.049)\end{array}$ \\
\hline Roman hub & & $\begin{array}{c}0.001 \\
(0.044)\end{array}$ & $\begin{array}{c}0.004 \\
(0.044)\end{array}$ & $\begin{array}{c}0.0001 \\
(0.044)\end{array}$ & $\begin{array}{c}0.003 \\
(0.043)\end{array}$ & $\begin{array}{c}0.008 \\
(0.043)\end{array}$ \\
\hline Roman road & & $\begin{array}{r}-0.025 \\
(0.074)\end{array}$ & $\begin{array}{r}-0.038 \\
(0.074)\end{array}$ & $\begin{array}{c}-0.027 \\
(0.074)\end{array}$ & $\begin{array}{r}-0.037 \\
(0.074)\end{array}$ & $\begin{array}{r}-0.027 \\
(0.073)\end{array}$ \\
\hline Years under Roman rule & & $\begin{array}{c}0.0001 \\
(0.0001)\end{array}$ & $\begin{array}{c}0.0002 \\
(0.0002)\end{array}$ & $\begin{array}{c}0.0001 \\
(0.0001)\end{array}$ & $\begin{array}{c}0.0002 \\
(0.0001)\end{array}$ & $\begin{array}{c}0.0001 \\
(0.0001)\end{array}$ \\
\hline Access to river & & $\begin{array}{r}-0.054 \\
(0.087)\end{array}$ & $\begin{array}{c}-0.067 \\
(0.084)\end{array}$ & $\begin{array}{c}-0.070 \\
(0.086)\end{array}$ & $\begin{array}{c}-0.066 \\
(0.084)\end{array}$ & $\begin{array}{r}-0.072 \\
(0.085)\end{array}$ \\
\hline Intercept & $\begin{array}{c}-1.124^{* * *} \\
(0.380)\end{array}$ & $\begin{array}{c}-0.477 \\
(0.554)\end{array}$ & $\begin{array}{c}-0.975^{* *} \\
(0.471)\end{array}$ & $\begin{array}{c}-0.572 \\
(0.597)\end{array}$ & $\begin{array}{c}-0.555 \\
(0.554)\end{array}$ & $\begin{array}{c}-0.627 \\
(0.580)\end{array}$ \\
\hline Observations & 214 & 214 & 214 & 214 & 214 & 214 \\
\hline
\end{tabular}

Notes: Robust standard errors clustered on the départment level for all models. ${ }^{* *}$ denote $p<0.01,{ }^{* *} p<0.05$, and ${ }^{\star} p<0.1$. 


\subsection{Estimates of Impact of Post Offices}

Table A3 reports the full result of Table $\mathrm{X}$ of the main text.

Table A3: OLS outputs of the impact of state capacity on the consolidation of authority in France.

\begin{tabular}{|c|c|c|c|c|c|c|c|}
\hline \multirow[t]{2}{*}{ Dependent variable } & \multicolumn{7}{|c|}{ Proportion of non-French-speaking communes } \\
\hline & $(1)$ & $(2)$ & (3) & (4) & (5) & (6) & (7) \\
\hline Log distance to Paris & $\begin{array}{l}0.181^{* *} \\
(0.086)\end{array}$ & $\begin{array}{l}0.188^{* *} \\
(0.085)\end{array}$ & $\begin{array}{l}0.180^{* *} \\
(0.083)\end{array}$ & $\begin{array}{l}0.175^{* *} \\
(0.084)\end{array}$ & $\begin{array}{l}0.168^{* *} \\
(0.081)\end{array}$ & $\begin{array}{l}0.174^{* *} \\
(0.081)\end{array}$ & $\begin{array}{l}0.166^{* *} \\
(0.080)\end{array}$ \\
\hline Log distance to post offices in 1559 & $\begin{array}{l}0.035^{* *} \\
(0.015)\end{array}$ & & & $\begin{array}{r}0.029^{*} \\
(0.016)\end{array}$ & $\begin{array}{c}0.024 \\
(0.015)\end{array}$ & & $\begin{array}{c}0.021 \\
(0.016)\end{array}$ \\
\hline Log distance to post offices in 1690 & & $\begin{array}{c}0.029^{*} \\
(0.016)\end{array}$ & & $\begin{array}{c}0.019 \\
(0.017)\end{array}$ & & $\begin{array}{c}0.015 \\
(0.015)\end{array}$ & $\begin{array}{c}0.008 \\
(0.016)\end{array}$ \\
\hline Log distance to post offices in 1792 & & & $\begin{array}{l}0.068^{* * *} \\
(0.021)\end{array}$ & & $\begin{array}{l}0.060^{* * *} \\
(0.022)\end{array}$ & $\begin{array}{l}0.062^{* * *} \\
(0.021)\end{array}$ & $\begin{array}{l}0.057^{* * *} \\
(0.022)\end{array}$ \\
\hline $\begin{array}{l}\text { Log distance to border } \\
\text { averaged, } 1400-1800\end{array}$ & $\begin{array}{r}-0.054 \\
(0.044)\end{array}$ & $\begin{array}{r}-0.064 \\
(0.043)\end{array}$ & $\begin{array}{r}-0.036 \\
(0.039)\end{array}$ & $\begin{array}{r}-0.056 \\
(0.042)\end{array}$ & $\begin{array}{r}-0.033 \\
(0.039)\end{array}$ & $\begin{array}{c}-0.038 \\
(0.039)\end{array}$ & $\begin{array}{r}-0.034 \\
(0.039)\end{array}$ \\
\hline $\begin{array}{l}\text { Log distance to coast } \\
\text { averaged, } 1400-1800\end{array}$ & $\begin{array}{c}0.021 \\
(0.026)\end{array}$ & $\begin{array}{c}0.028 \\
(0.026)\end{array}$ & $\begin{array}{c}0.032 \\
(0.025)\end{array}$ & $\begin{array}{c}0.026 \\
(0.026)\end{array}$ & $\begin{array}{c}0.031 \\
(0.025)\end{array}$ & $\begin{array}{c}0.035 \\
(0.025)\end{array}$ & $\begin{array}{c}0.033 \\
(0.025)\end{array}$ \\
\hline Elevation & $\begin{array}{c}-0.0001 \\
(0.0002)\end{array}$ & $\begin{array}{r}-0.0001 \\
(0.0003)\end{array}$ & $\begin{array}{c}-0.0001 \\
(0.0002)\end{array}$ & $\begin{array}{r}-0.0002 \\
(0.0002)\end{array}$ & $\begin{array}{c}-0.0001 \\
(0.0002)\end{array}$ & $\begin{array}{c}-0.0001 \\
(0.0002)\end{array}$ & $\begin{array}{r}-0.0002 \\
(0.0002)\end{array}$ \\
\hline Terrain ruggedness & $\begin{array}{r}-0.0004 \\
(0.0004)\end{array}$ & $\begin{array}{c}-0.001 \\
(0.0004)\end{array}$ & $\begin{array}{c}-0.001 \\
(0.0004)\end{array}$ & $\begin{array}{r}-0.0005 \\
(0.0004)\end{array}$ & $\begin{array}{c}-0.001 \\
(0.0004)\end{array}$ & $\begin{array}{c}-0.001 \\
(0.0004)\end{array}$ & $\begin{array}{c}-0.001 \\
(0.0004)\end{array}$ \\
\hline Years provincial estates held & $\begin{array}{c}0.001^{*} \\
(0.0003)\end{array}$ & $\begin{array}{c}0.001 \\
(0.0003)\end{array}$ & $\begin{array}{c}0.001^{*} \\
(0.0003)\end{array}$ & $\begin{array}{c}0.001^{*} \\
(0.0003)\end{array}$ & $\begin{array}{c}0.001^{*} \\
(0.0003)\end{array}$ & $\begin{array}{c}0.001^{*} \\
(0.0003)\end{array}$ & $\begin{array}{c}0.001^{*} \\
(0.0003)\end{array}$ \\
\hline Weighted log population growth by 1850 & $\begin{array}{c}0.014 \\
(0.040)\end{array}$ & $\begin{array}{c}0.011 \\
(0.040)\end{array}$ & $\begin{array}{c}0.019 \\
(0.040)\end{array}$ & $\begin{array}{c}0.022 \\
(0.040)\end{array}$ & $\begin{array}{c}0.030 \\
(0.040)\end{array}$ & $\begin{array}{c}0.026 \\
(0.040)\end{array}$ & $\begin{array}{c}0.033 \\
(0.040)\end{array}$ \\
\hline Number of printing presses by 1700 & $\begin{array}{r}-0.026 \\
(0.029)\end{array}$ & $\begin{array}{r}-0.032 \\
(0.029)\end{array}$ & $\begin{array}{r}-0.028 \\
(0.027)\end{array}$ & $\begin{array}{r}-0.025 \\
(0.029)\end{array}$ & $\begin{array}{r}-0.022 \\
(0.027)\end{array}$ & $\begin{array}{c}-0.027 \\
(0.027)\end{array}$ & $\begin{array}{r}-0.022 \\
(0.028)\end{array}$ \\
\hline Number of fair centers within $50 \mathrm{~km}$ & $\begin{array}{c}0.030 \\
(0.093)\end{array}$ & $\begin{array}{c}0.053 \\
(0.092)\end{array}$ & $\begin{array}{c}0.034 \\
(0.084)\end{array}$ & $\begin{array}{c}0.039 \\
(0.094)\end{array}$ & $\begin{array}{c}0.026 \\
(0.086)\end{array}$ & $\begin{array}{c}0.040 \\
(0.085)\end{array}$ & $\begin{array}{c}0.030 \\
(0.087)\end{array}$ \\
\hline Number of canals within $50 \mathrm{~km}$ & $\begin{array}{r}-0.059 \\
(0.039)\end{array}$ & $\begin{array}{r}-0.053 \\
(0.039)\end{array}$ & $\begin{array}{r}-0.063 \\
(0.042)\end{array}$ & $\begin{array}{r}-0.057 \\
(0.039)\end{array}$ & $\begin{array}{r}-0.065 \\
(0.041)\end{array}$ & $\begin{array}{c}-0.062 \\
(0.042)\end{array}$ & $\begin{array}{r}-0.064 \\
(0.042)\end{array}$ \\
\hline Number of universities & $\begin{array}{c}0.046 \\
(0.055)\end{array}$ & $\begin{array}{c}0.037 \\
(0.055)\end{array}$ & $\begin{array}{c}0.038 \\
(0.054)\end{array}$ & $\begin{array}{c}0.044 \\
(0.055)\end{array}$ & $\begin{array}{c}0.044 \\
(0.054)\end{array}$ & $\begin{array}{c}0.038 \\
(0.053)\end{array}$ & $\begin{array}{c}0.043 \\
(0.054)\end{array}$ \\
\hline Roman hub & $\begin{array}{r}-0.008 \\
(0.054)\end{array}$ & $\begin{array}{r}-0.015 \\
(0.054)\end{array}$ & $\begin{array}{r}-0.023 \\
(0.053)\end{array}$ & $\begin{array}{r}-0.006 \\
(0.055)\end{array}$ & $\begin{array}{r}-0.013 \\
(0.054)\end{array}$ & $\begin{array}{c}-0.019 \\
(0.054)\end{array}$ & $\begin{array}{r}-0.012 \\
(0.055)\end{array}$ \\
\hline Roman road & $\begin{array}{r}-0.008 \\
(0.081)\end{array}$ & $\begin{array}{r}-0.019 \\
(0.080)\end{array}$ & $\begin{array}{r}-0.013 \\
(0.084)\end{array}$ & $\begin{array}{r}-0.014 \\
(0.080)\end{array}$ & $\begin{array}{r}-0.010 \\
(0.082)\end{array}$ & $\begin{array}{c}-0.017 \\
(0.083)\end{array}$ & $\begin{array}{r}-0.013 \\
(0.082)\end{array}$ \\
\hline Years under Roman rule & $\begin{array}{c}0.0002 \\
(0.0001)\end{array}$ & $\begin{array}{c}0.0002 \\
(0.0002)\end{array}$ & $\begin{array}{c}0.0002 \\
(0.0001)\end{array}$ & $\begin{array}{c}0.0002 \\
(0.0001)\end{array}$ & $\begin{array}{c}0.0002 \\
(0.0001)\end{array}$ & $\begin{array}{c}0.0002 \\
(0.0001)\end{array}$ & $\begin{array}{c}0.0002 \\
(0.0001)\end{array}$ \\
\hline Access to river & $\begin{array}{r}-0.026 \\
(0.097)\end{array}$ & $\begin{array}{c}-0.028 \\
(0.097)\end{array}$ & $\begin{array}{r}-0.006 \\
(0.088)\end{array}$ & $\begin{array}{c}-0.020 \\
(0.097)\end{array}$ & $\begin{array}{c}-0.0001 \\
(0.089)\end{array}$ & $\begin{array}{r}-0.003 \\
(0.089)\end{array}$ & $\begin{array}{c}0.001 \\
(0.090)\end{array}$ \\
\hline Intercept & $\begin{array}{c}-0.714 \\
(0.603)\end{array}$ & $\begin{array}{r}-0.701 \\
(0.594)\end{array}$ & $\begin{array}{r}-0.804 \\
(0.557)\end{array}$ & $\begin{array}{r}-0.716 \\
(0.578)\end{array}$ & $\begin{array}{c}-0.804 \\
(0.542)\end{array}$ & $\begin{array}{c}-0.798 \\
(0.542)\end{array}$ & $\begin{array}{c}-0.801 \\
(0.536)\end{array}$ \\
\hline Observations & 214 & 214 & 214 & 214 & 214 & 214 & 214 \\
\hline
\end{tabular}


Table A4: OLS outputs of the impact of state capacity on the consolidation of authority in France.

\begin{tabular}{|c|c|c|c|c|c|c|c|}
\hline \multirow[t]{2}{*}{ Dependent variable } & \multicolumn{7}{|c|}{ Proportion of non-French-speaking populations } \\
\hline & (1) & $(2)$ & (3) & $(4)$ & $(5)$ & $(6)$ & (7) \\
\hline Log distance to Paris & $\begin{array}{l}0.164^{* *} \\
(0.079)\end{array}$ & $\begin{array}{c}0.168^{* *} \\
(0.076)\end{array}$ & $\begin{array}{l}0.164^{* *} \\
(0.076)\end{array}$ & $\begin{array}{l}0.157^{* *} \\
(0.075)\end{array}$ & $\begin{array}{l}0.152^{* *} \\
(0.074)\end{array}$ & $\begin{array}{l}0.156^{* *} \\
(0.073)\end{array}$ & $\begin{array}{l}0.149^{* *} \\
(0.072)\end{array}$ \\
\hline Log distance to post offices in 1559 & $\begin{array}{l}0.031^{* *} \\
(0.013)\end{array}$ & & & $\begin{array}{c}0.024^{*} \\
(0.014)\end{array}$ & $\begin{array}{c}0.022 \\
(0.013)\end{array}$ & & $\begin{array}{c}0.018 \\
(0.014)\end{array}$ \\
\hline Log distance to post offices in 1690 & & $\begin{array}{l}0.031^{* *} \\
(0.015)\end{array}$ & & $\begin{array}{c}0.023 \\
(0.017)\end{array}$ & & $\begin{array}{c}0.019 \\
(0.014)\end{array}$ & $\begin{array}{c}0.014 \\
(0.015)\end{array}$ \\
\hline Log distance to post offices in 1792 & & & $\begin{array}{l}0.059^{* * *} \\
(0.020)\end{array}$ & & $\begin{array}{l}0.051^{* *} \\
(0.021)\end{array}$ & $\begin{array}{l}0.051^{* * *} \\
(0.019)\end{array}$ & $\begin{array}{c}0.047^{* *} \\
(0.020)\end{array}$ \\
\hline $\begin{array}{l}\text { Log distance to border } \\
\text { averaged, } 1400-1800\end{array}$ & $\begin{array}{r}-0.051 \\
(0.043)\end{array}$ & $\begin{array}{r}-0.060 \\
(0.041)\end{array}$ & $\begin{array}{c}-0.035 \\
(0.038)\end{array}$ & $\begin{array}{r}-0.053 \\
(0.040)\end{array}$ & $\begin{array}{r}-0.033 \\
(0.037)\end{array}$ & $\begin{array}{c}-0.039 \\
(0.036)\end{array}$ & $\begin{array}{r}-0.035 \\
(0.036)\end{array}$ \\
\hline $\begin{array}{l}\text { Log distance to coast } \\
\text { averaged, } 1400-1800\end{array}$ & $\begin{array}{c}0.019 \\
(0.024)\end{array}$ & $\begin{array}{c}0.026 \\
(0.023)\end{array}$ & $\begin{array}{c}0.028 \\
(0.023)\end{array}$ & $\begin{array}{c}0.024 \\
(0.023)\end{array}$ & $\begin{array}{c}0.027 \\
(0.023)\end{array}$ & $\begin{array}{c}0.031 \\
(0.022)\end{array}$ & $\begin{array}{c}0.030 \\
(0.022)\end{array}$ \\
\hline Elevation & $\begin{array}{r}-0.0001 \\
(0.0002)\end{array}$ & $\begin{array}{c}-0.0002 \\
(0.0002)\end{array}$ & $\begin{array}{c}-0.0001 \\
(0.0002)\end{array}$ & $\begin{array}{r}-0.0002 \\
(0.0002)\end{array}$ & $\begin{array}{r}-0.0002 \\
(0.0002)\end{array}$ & $\begin{array}{c}-0.0002 \\
(0.0002)\end{array}$ & $\begin{array}{r}-0.0002 \\
(0.0002)\end{array}$ \\
\hline Terrain ruggedness & $\begin{array}{r}-0.0003 \\
(0.0004)\end{array}$ & $\begin{array}{c}-0.0004 \\
(0.0004)\end{array}$ & $\begin{array}{c}-0.001 \\
(0.0004)\end{array}$ & $\begin{array}{r}-0.0004 \\
(0.0004)\end{array}$ & $\begin{array}{r}-0.0005 \\
(0.0004)\end{array}$ & $\begin{array}{c}-0.001 \\
(0.0004)\end{array}$ & $\begin{array}{c}-0.001 \\
(0.0004)\end{array}$ \\
\hline Years provincial estates held & $\begin{array}{c}0.0004 \\
(0.0003)\end{array}$ & $\begin{array}{c}0.0004 \\
(0.0003)\end{array}$ & $\begin{array}{c}0.0004 \\
(0.0003)\end{array}$ & $\begin{array}{c}0.0004 \\
(0.0003)\end{array}$ & $\begin{array}{c}0.0004 \\
(0.0003)\end{array}$ & $\begin{array}{c}0.0004 \\
(0.0003)\end{array}$ & $\begin{array}{c}0.0004 \\
(0.0003)\end{array}$ \\
\hline Weighted log population growth by 1850 & $\begin{array}{c}0.009 \\
(0.035)\end{array}$ & $\begin{array}{c}0.010 \\
(0.035)\end{array}$ & $\begin{array}{c}0.013 \\
(0.035)\end{array}$ & $\begin{array}{c}0.019 \\
(0.035)\end{array}$ & $\begin{array}{c}0.023 \\
(0.035)\end{array}$ & $\begin{array}{c}0.022 \\
(0.035)\end{array}$ & $\begin{array}{c}0.028 \\
(0.035)\end{array}$ \\
\hline Number of printing presses by 1700 & $\begin{array}{c}-0.028 \\
(0.027)\end{array}$ & $\begin{array}{r}-0.033 \\
(0.027)\end{array}$ & $\begin{array}{r}-0.030 \\
(0.026)\end{array}$ & $\begin{array}{r}-0.028 \\
(0.027)\end{array}$ & $\begin{array}{r}-0.025 \\
(0.026)\end{array}$ & $\begin{array}{r}-0.029 \\
(0.026)\end{array}$ & $\begin{array}{r}-0.025 \\
(0.026)\end{array}$ \\
\hline Number of fair centers within $50 \mathrm{~km}$ & $\begin{array}{c}0.019 \\
(0.082)\end{array}$ & $\begin{array}{c}0.041 \\
(0.080)\end{array}$ & $\begin{array}{c}0.022 \\
(0.073)\end{array}$ & $\begin{array}{c}0.029 \\
(0.082)\end{array}$ & $\begin{array}{c}0.015 \\
(0.075)\end{array}$ & $\begin{array}{c}0.030 \\
(0.074)\end{array}$ & $\begin{array}{c}0.022 \\
(0.076)\end{array}$ \\
\hline Number of canals within $50 \mathrm{~km}$ & $\begin{array}{r}-0.049 \\
(0.035)\end{array}$ & $\begin{array}{r}-0.044 \\
(0.035)\end{array}$ & $\begin{array}{r}-0.053 \\
(0.038)\end{array}$ & $\begin{array}{r}-0.048 \\
(0.035)\end{array}$ & $\begin{array}{r}-0.054 \\
(0.037)\end{array}$ & $\begin{array}{r}-0.051 \\
(0.038)\end{array}$ & $\begin{array}{r}-0.053 \\
(0.038)\end{array}$ \\
\hline Number of universities & $\begin{array}{c}0.032 \\
(0.048)\end{array}$ & $\begin{array}{c}0.024 \\
(0.047)\end{array}$ & $\begin{array}{c}0.025 \\
(0.046)\end{array}$ & $\begin{array}{c}0.030 \\
(0.047)\end{array}$ & $\begin{array}{c}0.030 \\
(0.047)\end{array}$ & $\begin{array}{c}0.024 \\
(0.046)\end{array}$ & $\begin{array}{c}0.029 \\
(0.047)\end{array}$ \\
\hline Roman hub & $\begin{array}{c}0.013 \\
(0.045)\end{array}$ & $\begin{array}{c}0.007 \\
(0.044)\end{array}$ & $\begin{array}{r}-0.001 \\
(0.044)\end{array}$ & $\begin{array}{c}0.015 \\
(0.045)\end{array}$ & $\begin{array}{c}0.008 \\
(0.045)\end{array}$ & $\begin{array}{c}0.004 \\
(0.044)\end{array}$ & $\begin{array}{c}0.010 \\
(0.045)\end{array}$ \\
\hline Roman road & $\begin{array}{c}-0.024 \\
(0.073)\end{array}$ & $\begin{array}{r}-0.036 \\
(0.071)\end{array}$ & $\begin{array}{r}-0.028 \\
(0.074)\end{array}$ & $\begin{array}{r}-0.031 \\
(0.071)\end{array}$ & $\begin{array}{r}-0.026 \\
(0.072)\end{array}$ & $\begin{array}{r}-0.034 \\
(0.072)\end{array}$ & $\begin{array}{r}-0.031 \\
(0.071)\end{array}$ \\
\hline Years under Roman rule & $\begin{array}{c}0.0002 \\
(0.0001)\end{array}$ & $\begin{array}{c}0.0002 \\
(0.0001)\end{array}$ & $\begin{array}{c}0.0002 \\
(0.0001)\end{array}$ & $\begin{array}{c}0.0002 \\
(0.0001)\end{array}$ & $\begin{array}{c}0.0002 \\
(0.0001)\end{array}$ & $\begin{array}{c}0.0002 \\
(0.0001)\end{array}$ & $\begin{array}{c}0.0002 \\
(0.0001)\end{array}$ \\
\hline Access to river & $\begin{array}{r}-0.056 \\
(0.085)\end{array}$ & $\begin{array}{c}-0.057 \\
(0.086)\end{array}$ & $\begin{array}{c}-0.040 \\
(0.077)\end{array}$ & $\begin{array}{c}-0.050 \\
(0.086)\end{array}$ & $\begin{array}{c}-0.035 \\
(0.079)\end{array}$ & $\begin{array}{c}-0.036 \\
(0.079)\end{array}$ & $\begin{array}{r}-0.032 \\
(0.080)\end{array}$ \\
\hline Intercept & $\begin{array}{r}-0.590 \\
(0.558)\end{array}$ & $\begin{array}{r}-0.580 \\
(0.539)\end{array}$ & $\begin{array}{r}-0.667 \\
(0.515)\end{array}$ & $\begin{array}{c}-0.592 \\
(0.526)\end{array}$ & $\begin{array}{r}-0.668 \\
(0.502)\end{array}$ & $\begin{array}{r}-0.660 \\
(0.493)\end{array}$ & $\begin{array}{c}-0.662 \\
(0.488)\end{array}$ \\
\hline Observations & 214 & 214 & 214 & 214 & 214 & 214 & 214 \\
\hline
\end{tabular}


Table A5 reports the full result of Table $\mathrm{x}$ in the main text.

Table A5: OLS outputs exploring the variation of the post offices in 1792 in France.

\begin{tabular}{|c|c|c|c|c|}
\hline \multirow{2}{*}{$\begin{array}{c}\text { Dependent variable } \\
\text { Distance from Paris within }\end{array}$} & \multicolumn{4}{|c|}{ Proportion of non-French-speaking communes } \\
\hline & $\begin{array}{l}200 \mathrm{~km} \\
\text { (1) }\end{array}$ & $\begin{array}{l}400 \mathrm{~km} \\
\text { (2) }\end{array}$ & $\begin{array}{l}600 \mathrm{~km} \\
(3)\end{array}$ & $\begin{array}{l}800 \mathrm{~km} \\
(4)\end{array}$ \\
\hline Log distance to Paris & $\begin{array}{r}-0.375 \\
(0.276)\end{array}$ & $\begin{array}{c}0.330 \\
(0.294)\end{array}$ & $\begin{array}{l}0.541^{* * *} \\
(0.169)\end{array}$ & $\begin{array}{l}0.560^{* * *} \\
(0.123)\end{array}$ \\
\hline Post office in 1792 & $\begin{array}{r}-1.933 \\
(1.412)\end{array}$ & $\begin{array}{c}1.355 \\
(1.566)\end{array}$ & $\begin{array}{l}2.097^{* *} \\
(0.895)\end{array}$ & $\begin{array}{l}2.199^{* * *} \\
(0.689)\end{array}$ \\
\hline $\begin{array}{r}\text { Log distance to Paris } \times \\
\text { Post office in } 1792\end{array}$ & $\begin{array}{c}0.372 \\
(0.273)\end{array}$ & $\begin{array}{r}-0.257 \\
(0.297)\end{array}$ & $\begin{array}{c}-0.377^{* *} \\
(0.159)\end{array}$ & $\begin{array}{c}-0.394^{* * *} \\
(0.119)\end{array}$ \\
\hline $\begin{array}{l}\text { Log distance to border } \\
\text { averaged, } 1400-1800\end{array}$ & $\begin{array}{r}-0.036^{*} \\
(0.021)\end{array}$ & $\begin{array}{c}0.046 \\
(0.029)\end{array}$ & $\begin{array}{c}0.077 \\
(0.047)\end{array}$ & $\begin{array}{c}0.005 \\
(0.046)\end{array}$ \\
\hline $\begin{array}{l}\text { Log distance to coast } \\
\text { averaged, } 1400-1800\end{array}$ & $\begin{array}{r}-0.002 \\
(0.004)\end{array}$ & $\begin{array}{c}0.012 \\
(0.015)\end{array}$ & $\begin{array}{l}0.063^{* *} \\
(0.027)\end{array}$ & $\begin{array}{l}0.053^{* *} \\
(0.026)\end{array}$ \\
\hline Elevation & $\begin{array}{r}-0.00003 \\
(0.0001)\end{array}$ & $\begin{array}{c}0.0003 \\
(0.0003)\end{array}$ & $\begin{array}{r}-0.0001 \\
(0.0002)\end{array}$ & $\begin{array}{r}-0.0001 \\
(0.0002)\end{array}$ \\
\hline Terrain ruggedness & $\begin{array}{r}-0.0003 \\
(0.0002)\end{array}$ & $\begin{array}{c}-0.001 \\
(0.001)\end{array}$ & $\begin{array}{r}-0.0003 \\
(0.0005)\end{array}$ & $\begin{array}{c}-0.0005 \\
(0.0005)\end{array}$ \\
\hline Years provincial estates held & $\begin{array}{r}0.00003 \\
(0.0001)\end{array}$ & $\begin{array}{c}-0.0003 \\
(0.0002)\end{array}$ & $\begin{array}{c}0.0003 \\
(0.0003)\end{array}$ & $\begin{array}{c}0.001^{*} \\
(0.0003)\end{array}$ \\
\hline Weighted log population growth by 1850 & $\begin{array}{c}-0.012 \\
(0.014)\end{array}$ & $\begin{array}{c}0.074^{* *} \\
(0.034)\end{array}$ & $\begin{array}{c}0.021 \\
(0.039)\end{array}$ & $\begin{array}{c}0.018 \\
(0.040)\end{array}$ \\
\hline Number of printing presses by 1700 & $\begin{array}{r}-0.005 \\
(0.007)\end{array}$ & $\begin{array}{c}-0.004 \\
(0.023)\end{array}$ & $\begin{array}{r}-0.025 \\
(0.027)\end{array}$ & $\begin{array}{r}-0.030 \\
(0.027)\end{array}$ \\
\hline Number of fair centers within $50 \mathrm{~km}$ & $\begin{array}{r}-0.005 \\
(0.012)\end{array}$ & $\begin{array}{c}0.015 \\
(0.046)\end{array}$ & $\begin{array}{c}0.017 \\
(0.074)\end{array}$ & $\begin{array}{c}0.038 \\
(0.083)\end{array}$ \\
\hline Number of canals within $50 \mathrm{~km}$ & $\begin{array}{r}-0.004 \\
(0.005)\end{array}$ & $\begin{array}{c}0.018 \\
(0.024)\end{array}$ & $\begin{array}{r}-0.018 \\
(0.040)\end{array}$ & $\begin{array}{r}-0.064 \\
(0.042)\end{array}$ \\
\hline Number of universities & $\begin{array}{c}0.028^{*} \\
(0.014)\end{array}$ & $\begin{array}{c}0.052 \\
(0.039)\end{array}$ & $\begin{array}{c}0.035 \\
(0.055)\end{array}$ & $\begin{array}{c}0.046 \\
(0.053)\end{array}$ \\
\hline Roman hub & $\begin{array}{r}-0.005 \\
(0.012)\end{array}$ & $\begin{array}{r}-0.063 \\
(0.046)\end{array}$ & $\begin{array}{r}-0.001 \\
(0.055)\end{array}$ & $\begin{array}{r}-0.024 \\
(0.052)\end{array}$ \\
\hline Roman road & $\begin{array}{c}0.016 \\
(0.010)\end{array}$ & $\begin{array}{c}0.033 \\
(0.075)\end{array}$ & $\begin{array}{r}-0.044 \\
(0.093)\end{array}$ & $\begin{array}{r}-0.014 \\
(0.086)\end{array}$ \\
\hline Years under Roman rule & $\begin{array}{r}-0.00002 \\
(0.00002)\end{array}$ & $\begin{array}{c}0.0001 \\
(0.0001)\end{array}$ & $\begin{array}{c}0.0002 \\
(0.0002)\end{array}$ & $\begin{array}{c}0.0002 \\
(0.0001)\end{array}$ \\
\hline Access to river & $\begin{array}{c}0.014 \\
(0.013)\end{array}$ & $\begin{array}{r}-0.095 \\
(0.070)\end{array}$ & $\begin{array}{r}-0.050 \\
(0.084)\end{array}$ & $\begin{array}{c}-0.016 \\
(0.092)\end{array}$ \\
\hline Intercept & $\begin{array}{c}2.140 \\
(1.497)\end{array}$ & $\begin{array}{c}-1.944 \\
(1.571)\end{array}$ & $\begin{array}{c}-3.489^{* * *} \\
(0.981)\end{array}$ & $\begin{array}{c}-3.209^{* * *} \\
(0.760)\end{array}$ \\
\hline$N$ post offices in 1792 & 44 & 114 & 158 & 174 \\
\hline Observations & 49 & 128 & 182 & 209 \\
\hline
\end{tabular}

Notes: Robust standard errors clustered on the départment level for all models. ${ }^{* *}$ denote $p<0.01,{ }^{* *} p<0.05$, and ${ }^{\star} p<0.1$. The number of post offices in 1792 excludes that of Paris. 


\subsection{Estimates of Impact of Outside Influence}

Table A6 reports the full result of Table $\mathrm{x}$ in the main text.

Table A6: OLS outputs of the impact of outside factors on the consolidation of authority in France.

\begin{tabular}{|c|c|c|c|c|c|c|c|}
\hline \multirow[t]{2}{*}{ Dependent variable } & \multicolumn{7}{|c|}{ Proportion of non-French-speaking communes } \\
\hline & (1) & (2) & (3) & (4) & (5) & (6) & (7) \\
\hline Log distance to Paris & $\begin{array}{l}0.158^{* *} \\
(0.077)\end{array}$ & $\begin{array}{l}0.160^{* *} \\
(0.080)\end{array}$ & $\begin{array}{r}0.142^{*} \\
(0.082)\end{array}$ & $\begin{array}{l}0.178^{* *} \\
(0.084)\end{array}$ & $\begin{array}{l}0.143^{*} \\
(0.080)\end{array}$ & $\begin{aligned} 0.142^{*} \\
(0.084)\end{aligned}$ & $\begin{array}{l}0.166^{*} \\
(0.085)\end{array}$ \\
\hline Log distance to Wittenberg or Zürich & $\begin{array}{l}0.260^{* *} \\
(0.113)\end{array}$ & & & $\begin{array}{l}0.440^{* * *} \\
(0.141)\end{array}$ & & $\begin{array}{l}0.475^{* * *} \\
(0.141)\end{array}$ & $\begin{array}{l}0.424^{* * *} \\
(0.132)\end{array}$ \\
\hline Log distance to German imperial post & & $\begin{array}{c}0.027 \\
(0.058)\end{array}$ & & $\begin{array}{r}-0.113^{*} \\
(0.058)\end{array}$ & $\begin{array}{l}0.017 \\
(0.061)\end{array}$ & $\begin{array}{c}-0.146^{* *} \\
(0.057)\end{array}$ & $\begin{array}{l}-0.161^{* * *} \\
(0.056)\end{array}$ \\
\hline $\begin{array}{l}\text { Log distance to conflict location } \\
\text { averaged, } 1400-1700\end{array}$ & & & $\begin{array}{c}0.043 \\
(0.053)\end{array}$ & & $\begin{array}{l}0.034 \\
(0.055)\end{array}$ & $\begin{array}{c}0.077 \\
(0.060)\end{array}$ & $\begin{array}{l}0.080 \\
(0.059)\end{array}$ \\
\hline Log distance to post offices in 1559 & $\begin{array}{c}0.026 \\
(0.017)\end{array}$ & $\begin{array}{c}0.024 \\
(0.017)\end{array}$ & $\begin{array}{c}0.023 \\
(0.016)\end{array}$ & $\begin{array}{l}0.018 \\
(0.016)\end{array}$ & $\begin{array}{c}0.025 \\
(0.016)\end{array}$ & $\begin{array}{c}0.018 \\
(0.016)\end{array}$ & $\begin{array}{l}0.018 \\
(0.015)\end{array}$ \\
\hline Log distance to post offices in 1690 & $\begin{array}{r}-0.006 \\
(0.016)\end{array}$ & $\begin{array}{l}0.005 \\
(0.016)\end{array}$ & $\begin{array}{c}0.006 \\
(0.016)\end{array}$ & $\begin{array}{c}-0.001 \\
(0.016)\end{array}$ & $\begin{array}{c}0.004 \\
(0.016)\end{array}$ & $\begin{array}{c}-0.002 \\
(0.016)\end{array}$ & $\begin{array}{c}-0.001 \\
(0.016)\end{array}$ \\
\hline Log distance to post offices in 1792 & $\begin{array}{l}0.050^{* *} \\
(0.022)\end{array}$ & $\begin{array}{l}0.055^{* *} \\
(0.022)\end{array}$ & $\begin{array}{l}0.055^{* *} \\
(0.022)\end{array}$ & $\begin{array}{l}0.054^{* *} \\
(0.022)\end{array}$ & $\begin{array}{l}0.054^{* *} \\
(0.023)\end{array}$ & $\begin{array}{l}0.051^{* *} \\
(0.022)\end{array}$ & $\begin{array}{l}0.064^{* * *} \\
(0.024)\end{array}$ \\
\hline $\begin{array}{l}\text { Log distance to border } \\
\text { averaged, } 1400-1800\end{array}$ & $\begin{array}{r}-0.080^{*} \\
(0.043)\end{array}$ & $\begin{array}{c}-0.044 \\
(0.045)\end{array}$ & $\begin{array}{l}-0.037 \\
(0.037)\end{array}$ & $\begin{array}{r}-0.071^{*} \\
(0.043)\end{array}$ & $\begin{array}{c}-0.043 \\
(0.046)\end{array}$ & $\begin{array}{r}-0.070^{*} \\
(0.042)\end{array}$ & \\
\hline $\begin{array}{l}\text { Log distance to coast } \\
\text { averaged, } 1400-1800\end{array}$ & $\begin{array}{l}0.077^{* *} \\
(0.031)\end{array}$ & $\begin{array}{c}0.037 \\
(0.026)\end{array}$ & $\begin{array}{c}0.025 \\
(0.027)\end{array}$ & $\begin{array}{l}0.089^{* * *} \\
(0.032)\end{array}$ & $\begin{array}{c}0.029 \\
(0.028)\end{array}$ & $\begin{array}{l}0.076^{* *} \\
(0.033)\end{array}$ & $\begin{array}{r}0.060^{*} \\
(0.032)\end{array}$ \\
\hline Elevation & $\begin{array}{c}-0.0001 \\
(0.0002)\end{array}$ & $\begin{array}{r}-0.0002 \\
(0.0002)\end{array}$ & $\begin{array}{r}-0.0002 \\
(0.0002)\end{array}$ & $\begin{array}{c}-0.0001 \\
(0.0002)\end{array}$ & $\begin{array}{r}-0.0002 \\
(0.0002)\end{array}$ & $\begin{array}{c}-0.0001 \\
(0.0002)\end{array}$ & $\begin{array}{c}-0.0001 \\
(0.0002)\end{array}$ \\
\hline Terrain ruggedness & $\begin{array}{c}-0.001 \\
(0.0004)\end{array}$ & $\begin{array}{c}-0.001 \\
(0.0004)\end{array}$ & $\begin{array}{l}-0.001 \\
(0.0004)\end{array}$ & $\begin{array}{l}-0.001 \\
(0.0004)\end{array}$ & $\begin{array}{c}-0.001 \\
(0.0004)\end{array}$ & $\begin{array}{r}-0.0005 \\
(0.0004)\end{array}$ & $\begin{array}{r}-0.0005 \\
(0.0004)\end{array}$ \\
\hline Years provincial estates held & $\begin{array}{l}0.001^{*} \\
(0.0003)\end{array}$ & $\begin{array}{l}0.001^{*} \\
(0.0003)\end{array}$ & $\begin{array}{l}0.001 \\
(0.0003)\end{array}$ & $\begin{array}{l}0.001^{* *} \\
(0.0003)\end{array}$ & $\begin{array}{l}0.001 \\
(0.0003)\end{array}$ & $\begin{array}{l}0.001 \\
(0.0003)\end{array}$ & $\begin{array}{c}0.0004 \\
(0.0003)\end{array}$ \\
\hline Weighted log population growth by 1850 & $\begin{array}{c}0.041 \\
(0.038)\end{array}$ & $\begin{array}{c}0.035 \\
(0.040)\end{array}$ & $\begin{array}{c}0.036 \\
(0.041)\end{array}$ & $\begin{array}{c}0.040 \\
(0.039)\end{array}$ & $\begin{array}{c}0.036 \\
(0.041)\end{array}$ & $\begin{array}{c}0.044 \\
(0.040)\end{array}$ & $\begin{array}{c}0.048 \\
(0.042)\end{array}$ \\
\hline Number of printing presses by 1700 & $\begin{array}{c}-0.022 \\
(0.028)\end{array}$ & $\begin{array}{c}-0.022 \\
(0.028)\end{array}$ & $\begin{array}{c}-0.022 \\
(0.028)\end{array}$ & $\begin{array}{c}-0.022 \\
(0.027)\end{array}$ & $\begin{array}{c}-0.022 \\
(0.028)\end{array}$ & $\begin{array}{r}-0.020 \\
(0.028)\end{array}$ & $\begin{array}{c}-0.021 \\
(0.028)\end{array}$ \\
\hline Number of fair centers within $50 \mathrm{~km}$ & $\begin{array}{c}-0.007 \\
(0.077)\end{array}$ & $\begin{array}{c}0.022 \\
(0.084)\end{array}$ & $\begin{array}{c}0.037 \\
(0.087)\end{array}$ & $\begin{array}{c}0.003 \\
(0.074)\end{array}$ & $\begin{array}{l}0.030 \\
(0.085)\end{array}$ & $\begin{array}{l}0.020 \\
(0.075)\end{array}$ & $\begin{array}{l}0.017 \\
(0.079)\end{array}$ \\
\hline Number of canals within $50 \mathrm{~km}$ & $\begin{array}{c}-0.054 \\
(0.038)\end{array}$ & $\begin{array}{c}-0.062 \\
(0.041)\end{array}$ & $\begin{array}{c}-0.064 \\
(0.041)\end{array}$ & $\begin{array}{c}-0.056 \\
(0.038)\end{array}$ & $\begin{array}{r}-0.062 \\
(0.041)\end{array}$ & $\begin{array}{c}-0.057 \\
(0.037)\end{array}$ & $\begin{array}{c}-0.058 \\
(0.039)\end{array}$ \\
\hline Number of universities & $\begin{array}{c}0.036 \\
(0.053)\end{array}$ & $\begin{array}{c}0.045 \\
(0.054)\end{array}$ & $\begin{array}{c}0.049 \\
(0.056)\end{array}$ & $\begin{array}{c}0.021 \\
(0.051)\end{array}$ & $\begin{array}{c}0.049 \\
(0.056)\end{array}$ & $\begin{array}{c}0.028 \\
(0.051)\end{array}$ & $\begin{array}{c}0.031 \\
(0.052)\end{array}$ \\
\hline Roman hub & $\begin{array}{c}-0.037 \\
(0.054)\end{array}$ & $\begin{array}{c}-0.017 \\
(0.053)\end{array}$ & $\begin{array}{c}-0.006 \\
(0.054)\end{array}$ & $\begin{array}{c}-0.034 \\
(0.052)\end{array}$ & $\begin{array}{c}-0.010 \\
(0.050)\end{array}$ & $\begin{array}{c}-0.020 \\
(0.049)\end{array}$ & $\begin{array}{c}-0.009 \\
(0.049)\end{array}$ \\
\hline Roman road & $\begin{array}{c}-0.017 \\
(0.076)\end{array}$ & $\begin{array}{c}-0.013 \\
(0.082)\end{array}$ & $\begin{array}{c}-0.027 \\
(0.077)\end{array}$ & $\begin{array}{c}-0.018 \\
(0.074)\end{array}$ & $\begin{array}{c}-0.024 \\
(0.076)\end{array}$ & $\begin{array}{c}-0.042 \\
(0.068)\end{array}$ & $\begin{array}{c}-0.051 \\
(0.072)\end{array}$ \\
\hline Years under Roman rule & $\begin{array}{c}0.0002 \\
(0.0001)\end{array}$ & $\begin{array}{c}0.0002 \\
(0.0001)\end{array}$ & $\begin{array}{c}0.0002 \\
(0.0001)\end{array}$ & $\begin{array}{c}0.0002 \\
(0.0001)\end{array}$ & $\begin{array}{c}0.0002 \\
(0.0001)\end{array}$ & $\begin{array}{c}0.0002 \\
(0.0001)\end{array}$ & $\begin{array}{c}0.0002 \\
(0.0002)\end{array}$ \\
\hline Access to river & $\begin{array}{c}-0.013 \\
(0.088)\end{array}$ & $\begin{array}{c}-0.002 \\
(0.090)\end{array}$ & $\begin{array}{c}0.003 \\
(0.087)\end{array}$ & $\begin{array}{c}-0.010 \\
(0.091)\end{array}$ & $\begin{array}{c}0.001 \\
(0.088)\end{array}$ & $\begin{array}{c}-0.006 \\
(0.087)\end{array}$ & $\begin{array}{c}0.007 \\
(0.084)\end{array}$ \\
\hline Intercept & $\begin{array}{c}-2.311^{* * *} \\
(0.816)\end{array}$ & $\begin{array}{r}-0.890^{*} \\
(0.536)\end{array}$ & $\begin{array}{c}-0.805 \\
(0.543)\end{array}$ & $\begin{array}{c}-2.989^{* * *} \\
(0.903)\end{array}$ & $\begin{array}{c}-0.861 \\
(0.531)\end{array}$ & $\begin{array}{c}-3.090^{* * *} \\
(0.945)\end{array}$ & $\begin{array}{c}-3.114^{* * *} \\
(0.955)\end{array}$ \\
\hline Observations & 214 & 214 & 214 & 214 & 214 & 214 & 214 \\
\hline
\end{tabular}

Notes: Robust standard errors clustered on the départment level for all models. ${ }^{* *}$ denote $p<0.01{ }^{* *} p<0.05$, and ${ }^{\star} p<0.1$. 
Table A7: OLS outputs of the impact of outside factors on the consolidation of authority in France.

\begin{tabular}{|c|c|c|c|c|c|c|c|}
\hline \multirow{2}{*}{ Dependent variable } & \multicolumn{7}{|c|}{ Proportion of non-French-speaking populations } \\
\hline & $(1)$ & (2) & (3) & $(4)$ & $(5)$ & $(6)$ & $(7)$ \\
\hline Log distance to Paris & $\begin{array}{l}0.143^{* *} \\
(0.070)\end{array}$ & $\begin{array}{l}0.144^{* *} \\
(0.072)\end{array}$ & $\begin{array}{c}0.135^{*} \\
(0.073)\end{array}$ & $\begin{array}{l}0.158^{* *} \\
(0.075)\end{array}$ & $\begin{array}{l}0.136^{*} \\
(0.072)\end{array}$ & $\begin{array}{l}0.135^{*} \\
(0.075)\end{array}$ & $\begin{array}{l}0.157^{* *} \\
(0.076)\end{array}$ \\
\hline Log distance to Wittenberg or Zürich & $\begin{array}{c}0.202^{*} \\
(0.108)\end{array}$ & & & $\begin{array}{l}0.341^{* *} \\
(0.134)\end{array}$ & & $\begin{array}{l}0.363^{* * *} \\
(0.137)\end{array}$ & $\begin{array}{l}0.317^{* *} \\
(0.129)\end{array}$ \\
\hline Log distance to German imperial post & & $\begin{array}{c}0.022 \\
(0.044)\end{array}$ & & $\begin{array}{r}-0.087^{*} \\
(0.052)\end{array}$ & $\begin{array}{c}0.017 \\
(0.046)\end{array}$ & $\begin{array}{c}-0.109^{* *} \\
(0.054)\end{array}$ & $\begin{array}{c}-0.122^{* *} \\
(0.058)\end{array}$ \\
\hline $\begin{array}{l}\text { Log distance to conflict location } \\
\text { averaged, } 1400-1700\end{array}$ & & & $\begin{array}{c}0.025 \\
(0.047)\end{array}$ & & $\begin{array}{c}0.017 \\
(0.050)\end{array}$ & $\begin{array}{c}0.050 \\
(0.054)\end{array}$ & $\begin{array}{c}0.052 \\
(0.054)\end{array}$ \\
\hline Log distance to post offices in 1559 & $\begin{array}{c}0.021 \\
(0.014)\end{array}$ & $\begin{array}{c}0.020 \\
(0.015)\end{array}$ & $\begin{array}{c}0.019 \\
(0.014)\end{array}$ & $\begin{array}{c}0.015 \\
(0.015)\end{array}$ & $\begin{array}{c}0.020 \\
(0.015)\end{array}$ & $\begin{array}{c}0.015 \\
(0.015)\end{array}$ & $\begin{array}{c}0.015 \\
(0.014)\end{array}$ \\
\hline Log distance to post offices in 1690 & $\begin{array}{c}0.003 \\
(0.015)\end{array}$ & $\begin{array}{c}0.011 \\
(0.015)\end{array}$ & $\begin{array}{c}0.013 \\
(0.015)\end{array}$ & $\begin{array}{c}0.007 \\
(0.015)\end{array}$ & $\begin{array}{c}0.011 \\
(0.015)\end{array}$ & $\begin{array}{c}0.006 \\
(0.015)\end{array}$ & $\begin{array}{c}0.007 \\
(0.015)\end{array}$ \\
\hline Log distance to post offices in 1792 & $\begin{array}{l}0.041^{* *} \\
(0.020)\end{array}$ & $\begin{array}{l}0.045^{* *} \\
(0.021)\end{array}$ & $\begin{array}{l}0.045^{* *} \\
(0.021)\end{array}$ & $\begin{array}{l}0.044^{* *} \\
(0.020)\end{array}$ & $\begin{array}{l}0.044^{* *} \\
(0.021)\end{array}$ & $\begin{array}{l}0.042^{* *} \\
(0.020)\end{array}$ & $\begin{array}{l}0.054^{* *} \\
(0.023)\end{array}$ \\
\hline $\begin{array}{l}\text { Log distance to border } \\
\text { averaged, 1400-1800 }\end{array}$ & $\begin{array}{r}-0.071^{*} \\
(0.041)\end{array}$ & $\begin{array}{r}-0.043 \\
(0.040)\end{array}$ & $\begin{array}{r}-0.037 \\
(0.035)\end{array}$ & $\begin{array}{r}-0.064 \\
(0.040)\end{array}$ & $\begin{array}{r}-0.042 \\
(0.041)\end{array}$ & $\begin{array}{c}-0.063 \\
(0.040)\end{array}$ & \\
\hline $\begin{array}{l}\text { Log distance to coast } \\
\text { averaged, } 1400-1800\end{array}$ & $\begin{array}{l}0.064^{* *} \\
(0.027)\end{array}$ & $\begin{array}{c}0.033 \\
(0.022)\end{array}$ & $\begin{array}{c}0.025 \\
(0.024)\end{array}$ & $\begin{array}{l}0.074^{* *} \\
(0.029)\end{array}$ & $\begin{array}{c}0.029 \\
(0.025)\end{array}$ & $\begin{array}{l}0.065^{* *} \\
(0.030)\end{array}$ & $\begin{array}{c}0.051^{*} \\
(0.029)\end{array}$ \\
\hline Elevation & $\begin{array}{r}-0.0001 \\
(0.0002)\end{array}$ & $\begin{array}{r}-0.0002 \\
(0.0002)\end{array}$ & $\begin{array}{r}-0.0002 \\
(0.0002)\end{array}$ & $\begin{array}{c}-0.0001 \\
(0.0002)\end{array}$ & $\begin{array}{r}-0.0002 \\
(0.0002)\end{array}$ & $\begin{array}{r}-0.0001 \\
(0.0002)\end{array}$ & $\begin{array}{r}-0.0001 \\
(0.0002)\end{array}$ \\
\hline Terrain ruggedness & $\begin{array}{c}-0.0004 \\
(0.0004)\end{array}$ & $\begin{array}{c}-0.001 \\
(0.0004)\end{array}$ & $\begin{array}{c}-0.001 \\
(0.0004)\end{array}$ & $\begin{array}{c}-0.0004 \\
(0.0004)\end{array}$ & $\begin{array}{l}-0.001 \\
(0.0004)\end{array}$ & $\begin{array}{r}-0.0004 \\
(0.0004)\end{array}$ & $\begin{array}{c}-0.0004 \\
(0.0004)\end{array}$ \\
\hline Years provincial estates held & $\begin{array}{c}0.0004 \\
(0.0003)\end{array}$ & $\begin{array}{c}0.0004 \\
(0.0003)\end{array}$ & $\begin{array}{c}0.0004 \\
(0.0003)\end{array}$ & $\begin{array}{c}0.0004 \\
(0.0003)\end{array}$ & $\begin{array}{c}0.0004 \\
(0.0003)\end{array}$ & $\begin{array}{c}0.0004 \\
(0.0003)\end{array}$ & $\begin{array}{c}0.0003 \\
(0.0003)\end{array}$ \\
\hline Weighted $\log$ population growth by 1850 & $\begin{array}{c}0.034 \\
(0.034)\end{array}$ & $\begin{array}{c}0.029 \\
(0.035)\end{array}$ & $\begin{array}{c}0.029 \\
(0.036)\end{array}$ & $\begin{array}{c}0.033 \\
(0.034)\end{array}$ & $\begin{array}{c}0.030 \\
(0.036)\end{array}$ & $\begin{array}{c}0.036 \\
(0.035)\end{array}$ & $\begin{array}{c}0.039 \\
(0.037)\end{array}$ \\
\hline Number of printing presses by 1700 & $\begin{array}{r}-0.025 \\
(0.027)\end{array}$ & $\begin{array}{r}-0.025 \\
(0.027)\end{array}$ & $\begin{array}{r}-0.025 \\
(0.027)\end{array}$ & $\begin{array}{r}-0.025 \\
(0.026)\end{array}$ & $\begin{array}{r}-0.025 \\
(0.027)\end{array}$ & $\begin{array}{r}-0.024 \\
(0.026)\end{array}$ & $\begin{array}{r}-0.025 \\
(0.027)\end{array}$ \\
\hline Number of fair centers within $50 \mathrm{~km}$ & $\begin{array}{r}-0.007 \\
(0.068)\end{array}$ & $\begin{array}{c}0.015 \\
(0.074)\end{array}$ & $\begin{array}{c}0.026 \\
(0.076)\end{array}$ & $\begin{array}{c}0.0003 \\
(0.066)\end{array}$ & $\begin{array}{c}0.019 \\
(0.074)\end{array}$ & $\begin{array}{c}0.012 \\
(0.067)\end{array}$ & $\begin{array}{c}0.009 \\
(0.070)\end{array}$ \\
\hline Number of canals within $50 \mathrm{~km}$ & $\begin{array}{r}-0.045 \\
(0.035)\end{array}$ & $\begin{array}{c}-0.051 \\
(0.038)\end{array}$ & $\begin{array}{r}-0.053 \\
(0.038)\end{array}$ & $\begin{array}{r}-0.047 \\
(0.035)\end{array}$ & $\begin{array}{r}-0.051 \\
(0.038)\end{array}$ & $\begin{array}{r}-0.048 \\
(0.035)\end{array}$ & $\begin{array}{r}-0.048 \\
(0.036)\end{array}$ \\
\hline Number of universities & $\begin{array}{c}0.023 \\
(0.045)\end{array}$ & $\begin{array}{c}0.031 \\
(0.047)\end{array}$ & $\begin{array}{c}0.032 \\
(0.049)\end{array}$ & $\begin{array}{c}0.012 \\
(0.045)\end{array}$ & $\begin{array}{c}0.032 \\
(0.049)\end{array}$ & $\begin{array}{c}0.016 \\
(0.046)\end{array}$ & $\begin{array}{c}0.019 \\
(0.046)\end{array}$ \\
\hline Roman hub & $\begin{array}{r}-0.009 \\
(0.046)\end{array}$ & $\begin{array}{c}0.006 \\
(0.045)\end{array}$ & $\begin{array}{c}0.014 \\
(0.044)\end{array}$ & $\begin{array}{r}-0.007 \\
(0.045)\end{array}$ & $\begin{array}{c}0.010 \\
(0.043)\end{array}$ & $\begin{array}{c}0.002 \\
(0.042)\end{array}$ & $\begin{array}{c}0.012 \\
(0.042)\end{array}$ \\
\hline Roman road & $\begin{array}{r}-0.034 \\
(0.067)\end{array}$ & $\begin{array}{r}-0.031 \\
(0.071)\end{array}$ & $\begin{array}{r}-0.039 \\
(0.067)\end{array}$ & $\begin{array}{r}-0.034 \\
(0.065)\end{array}$ & $\begin{array}{r}-0.036 \\
(0.066)\end{array}$ & $\begin{array}{r}-0.050 \\
(0.060)\end{array}$ & $\begin{array}{r}-0.058 \\
(0.063)\end{array}$ \\
\hline Years under Roman rule & $\begin{array}{c}0.0002 \\
(0.0001)\end{array}$ & $\begin{array}{c}0.0002 \\
(0.0001)\end{array}$ & $\begin{array}{c}0.0002 \\
(0.0001)\end{array}$ & $\begin{array}{c}0.0002 \\
(0.0001)\end{array}$ & $\begin{array}{c}0.0002 \\
(0.0001)\end{array}$ & $\begin{array}{c}0.0002 \\
(0.0001)\end{array}$ & $\begin{array}{c}0.0002 \\
(0.0001)\end{array}$ \\
\hline Access to river & $\begin{array}{c}-0.043 \\
(0.078)\end{array}$ & $\begin{array}{c}-0.035 \\
(0.079)\end{array}$ & $\begin{array}{c}-0.031 \\
(0.078)\end{array}$ & $\begin{array}{c}-0.041 \\
(0.079)\end{array}$ & $\begin{array}{c}-0.033 \\
(0.078)\end{array}$ & $\begin{array}{r}-0.038 \\
(0.078)\end{array}$ & $\begin{array}{r}-0.027 \\
(0.075)\end{array}$ \\
\hline Intercept & $\begin{array}{c}-1.835^{* *} \\
(0.778)\end{array}$ & $\begin{array}{c}-0.732 \\
(0.494)\end{array}$ & $\begin{array}{c}-0.665 \\
(0.492)\end{array}$ & $\begin{array}{c}-2.358^{* * *} \\
(0.847)\end{array}$ & $\begin{array}{r}-0.718 \\
(0.487)\end{array}$ & $\begin{array}{c}-2.423^{* * *} \\
(0.885)\end{array}$ & $\begin{array}{c}-2.445^{* * *} \\
(0.892)\end{array}$ \\
\hline Observations & 214 & 214 & 214 & 214 & 214 & 214 & 214 \\
\hline
\end{tabular}

Notes: Robust standard errors clustered on the départment level for all models. ${ }^{* *}$ denote $p<0.01,{ }^{* *} p<0.05$, and ${ }^{\star} p<0.1$. 
Table A8: OLS outputs of Protestantism.

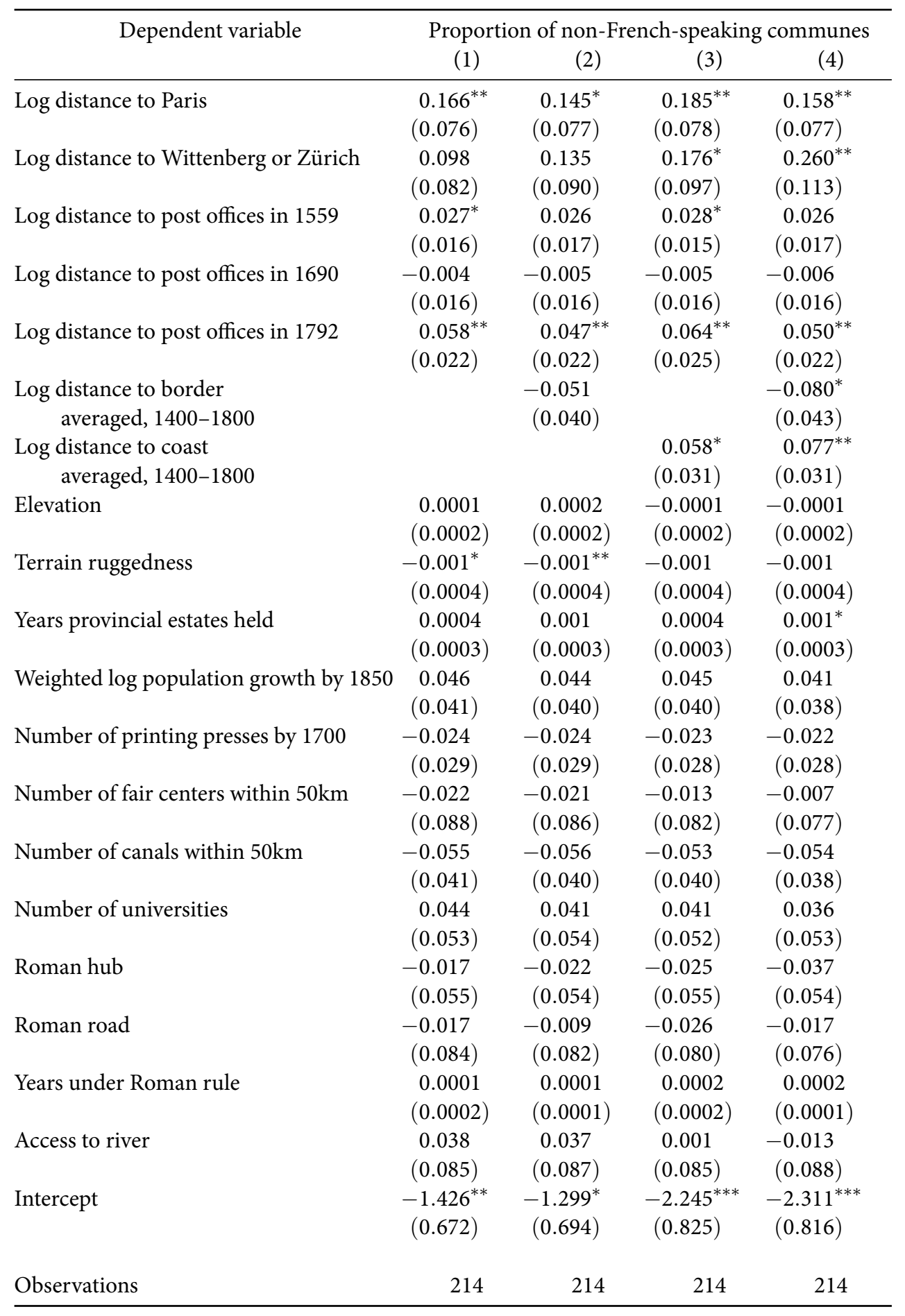

Notes: Robust standard errors clustered on the départment level for all models. ${ }^{* *}$ denote $p<0.01,{ }^{* *} p<0.05$, and ${ }^{\star} p<0.1$. 